\title{
Review on the acute Daphnia magna toxicity test - Evaluation of the sensitivity and the precision of assays performed with organisms from laboratory cultures or hatched from dormant eggs
}

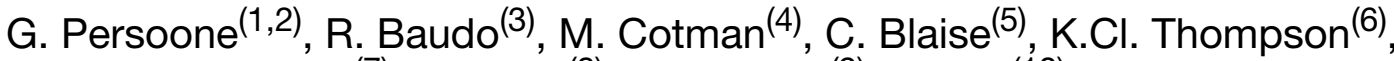 \\ M. Moreira-Santos ${ }^{(7)}$, B. Vollat ${ }^{(8)}$, A. Törökne ${ }^{(9)}$, T. Han $^{(10)}$ \\ Received May 13, 2009 / Reçu le 13 mai 2009 \\ Accepted June 26, 2009 / Accepté le 26 juin 2009
}

\section{EXECUTIVE SUMMARY}

Key-words: $\quad$ One of the most internationally used bioassays for toxicity screening of review, Daphnia magna, toxicity test, microbiotest, dormant eggs chemicals and for toxicity monitoring of effluents and contaminated waters is the acute toxicity test with daphnid crustaceans, and in particular that performed with Daphnia magna.

Standard methods have been developed for this assay that were gradually endorsed by national and international organisations dealing with toxicity testing procedures, in view of its application within a regulatory framework. As for all toxicity tests, the organisms used for the acute $D$. magna assay have to be obtained from live stocks which are cultured in the laboratory on live food (micro-algae).

Unsurprisingly the various standard protocols of this particular assay differ - at least to a certain extent - with regard to the test organism culturing conditions. In addition, some technical aspects of the toxicity test such as the effect criterion (mortality of immobility), the exposure time, the type of dilution water, etc., also vary from one standard to another.

Although this particular assay is currently used in many countries, the technical and biological problems inherent in year-round culturing and availability of the biological material and the culturing/maintenance costs of live stocks restrict its application to a limited number of highly specialised laboratories.

This fundamental bottleneck in toxicity testing triggered investigations which brought forward the concept of "microbiotests" or "small-scale" toxicity tests.

(1) Ghent University, Laboratory for Environmental Toxicology and Aquatic Ecology, Ghent, Belgium, Guido.persoone@ugent.be

(2) MicroBioTests Inc., Mariakerke, Belgium

(3) CNR - Istituto per lo Studio degli Ecosistemi, Verbania, Pallanza, Italy

(4) National Institute of Chemistry, Laboratory for Environmental Science and Engineering, Ljubljana, Slovenia

(5) Fluvial Ecosystems Research, Aquatic Ecosystem Protection Research Division, Water Science and Technology Directorate, Environment Canada, Montreal, Canada

(6) ALcontrol Laboratories, Rotherham, England

(7) MAR-CMA - Instituto do Mar, Department of Zoology, University of Coimbra, Coimbra, Portugal

(8) Cemagref, Laboratoire d'Écotoxicologie, Lyon, France

(9) National Institute of Environmental Health, Department of Hygiene, Water Biology and Ecotoxicology,

Budapest, Hungary

(10) University of Incheon, Department of Biology, Incheon, South Korea 
"Culture/maintenance free" aquatic microbiotests with species of different phylogenetic groups were developed in the early 1990s at the Laboratory for Environmental Toxicology and Aquatic Ecology at the Ghent University in Belgium.

These assays which were given the generic name "Toxkits", are unique in that they employ dormant stages ("cryptobiotic eggs") of the test species, which can be stored for long periods of time and "hatched" at the time of performance of the assays.

One of these microbiotests is the Daphtoxkit F magna, which is currently used in many laboratories worldwide for research as well as for toxicity monitoring purposes.

The microbiotest technology has several advantages in comparison to the "traditional" tests based on laboratory cultures, especially its independence of the stock culturing burden. However, the acceptance (or possible non-acceptance) of performing assays with test organisms obtained from "dormant eggs" should be clearly dictated by the "sensitivity" and "precision" criteria of the former assays in comparison to the latter.

The first part of this review therefore thoroughly reviews the scientific literature and of data obtained from various laboratories for assays performed with either $D$. magna test organisms obtained from lab cultures or hatched from dormant eggs.

Attention has focused on data of quality control tests performed on reference chemicals, and in particular on potassium dichromate $\left(\mathrm{K}_{2} \mathrm{Cr}_{2} \mathrm{O}_{7}\right)$ for which an acceptability range of $0.6-2.1 \mathrm{mg} \cdot \mathrm{L}^{-1}$ has been set in ISO standard 6341 for the $24 \mathrm{~h}$ EC50 of the acute $D$. magna assay.

Mean EC50s, standard deviations and variation coefficients were calculated from the collected data, all of which are presented in tables and figures and discussed in detail.

The major conclusions drawn from the analysis of the large number of quality control (QC) data on the acute $D$. magna toxicity test are that :

(1) Virtually all results from assays performed with Daphnias taken from lab cultures or with Daphnia microbiotests are within the acceptability range set by ISO standard 6341 for the reference chemical potassium dichromate. (2) The mean $24 \mathrm{~h}$ EC50s of the Daphnia microbiotests performed in different laboratories are within the range of the mean EC50s of the assays based on lab cultures, and the variation coefficients (20 to $30 \%$ ) are similar.

(3) The precision - in terms of the long term in house variability - of the quality control Daphnia microbiotests is as good as that of the QC tests based on lab cultures.

The review further reports on intra-laboratory sensitivity comparison studies performed during the last 15 years on pure chemicals and on natural samples, with both laboratory cultured organisms and Daphnias hatched from dormant eggs. These studies carried out in different laboratories showed EC50 correlation coefficients of 0.86 to 0.98 , corroborating a similar sensitivity of the two types of test organisms.

The third part of the review reports and analyses data on proficiency ringtests on the acute $D$. magna assay which have been organised in different countries since 2002 with either reference chemicals or with natural samples, and in which part of the laboratories performed their assays with Daphnia microbiotests and others with lab cultured Daphnias.

The conclusions drawn from all the ringtests indicate that the sensitivity of Daphnia neonates hatched from dormant eggs is similar to that of test organisms taken from lab cultures and that in most cases the precision of the Daphnia microbiotest is superior to that of the assays based on lab cultures. 
The review finally addresses the issue of possible sensitivity differences of Daphnias hatched from dormant eggs which are produced by different D. magna strains.

From these investigations it appeared that the EC50s from assays performed with Daphnias hatched from dormant eggs of different strains did not differ significantly from those from assays undertaken with daphnids from lab cultures.

The obvious advantages of Daphnia microbiotests over tests with Daphnias stemming from lab cultures have led to the worldwide use of these culture/maintenance free and low cost small-scale assays in both research and toxicity monitoring.

The Daphnia microbiotest is in current use in several countries for toxicity testing in a regulatory framework, and recent calculations indicate that about 10000 acute $D$. magna assays are now performed annually with neonates hatched from dormant eggs.

The use of dormant eggs to obtain test organisms independently of stock culturing has recently also been accepted in international standards for toxicity testing. ISO standard 20665 (2008) related to the determination of chronic toxicity with Ceriodaphnia dubia, and ISO standard 20666 (2008) for the determination of the chronic toxicity with Brachionus calyciflorus in $48 \mathrm{~h}$, both indicate that the assays can be conducted with organisms hatched from dormant eggs.

On the basis of the extensive scientific evidence provided in this review that is justifiably supported by the two ISO methods mentioned above, the authors therefore recommend that the use of Daphnias hatched from dormant eggs should also be incorporated in national and international standards, as an alternative to the use of Daphnias taken from laboratory cultures.

\section{RÉSUMÉ ÉTENDU}

Revue de l'essai aigu de toxicité vis-à-vis de Daphnia magna - Évaluation de la sensibilité et de la précision des résultats obtenus à partir d'organismes provenant d'élevages de laboratoires ou d'organismes éclos d'œufs de dormance

Mots-clés:
revue,
Daphnia magna,
test de toxicité,
microbiotest,
œufs de
dormance

L'essai de toxicité aigu vis-à-vis de daphnies, en particulier celui entrepris avec Daphnia magna, est l'un des plus populaires utilisés au niveau international pour le dépistage de la toxicité de produits chimiques et la surveillance d'effluents et d'eaux contaminées.

Avec le temps, des méthodes normalisées développées avec cet essai ont été reconnues par des organismes nationaux et internationaux intéressés par les tests biologiques, en vue de son application dans un contexte réglementaire.

À l'instar des autres tests biologiques, les organismes intervenant dans l'essai aigu avec $D$. magna proviennent d'élevages de laboratoires nourris de micro-algues. II n'est pas surprenant de constater que les différentes procédures standard varient jusqu'à un certain point en ce qui a trait aux conditions d'élevage des animaux tests.

Par ailleurs, pour cet essai il ne semble pas non plus exister de constance sur certains aspects techniques liés par exemple au paramètre de toxicité (létalité ou immobilité), au temps d'exposition, à la composition de l'eau de dilution, lesquels peuvent varier de façon marquée.

Bien que cet essai soit maintenant conduit dans beaucoup de pays, les contraintes techniques et biologiques associées à l'élevage des organismes, ainsi qu'à leur 
disponibilité continuelle, restreignent « de facto » son application à un nombre limité de laboratoires spécialisés.

Ce problème, critique pour l'entreprise de tests de toxicité, a promu des études qui ont abouti à des essais « à petite échelle », connus maintenant sous l'appellation de « microbiotests ».

De tels microbiotests, indépendants de tout souci d'élevage et d'entretien, ont été développés au début des années 1990 avec des organismes de différents groupes phylogéniques, au Laboratoire de Toxicologie environmentale et d'Écologie aquatique de l'Université de Gand en Belgique.

Baptisés «Toxkits », ces essais s'avèrent uniques par leur emploi de stades d'œufs de dormance (œufs cryptobiotiques) pour chaque espèce d'organisme concernée, ce qui permet au matériel biologique « au stade inerte » d'être entreposé durant de longues périodes et éclos au moment du démarrage d'un test de toxicité.

L'un de ces microbiotests est le Daphtoxkit $F$ magna, présentement en usage à l'échelle mondiale pour des besoins de recherche ou de surveillance de toxicité.

La technologie des microbiotests offre plusieurs avantages sur celle des essais traditionnels puisqu'elle assure l'indépendance du besoin d'élevage et de maintien de stocks des organismes tests.

Cependant, la reconnaissance par la communauté scientifique de la conduite d'essais avec des organismes éclos d'œufs de dormance passe obligatoirement par une preuve de sensibilité et de précision équivalente à celle de l'essai traditionnel.

La première partie de cette revue rappelle les principales études et résultats obtenus par divers laboratoires avec des organismes provenant d'élevages en laboratoire, et de daphnies éclos d'œufs de dormance.

Des données de contrôle de qualité entrepris avec des produits chimiques de référence, notamment le bichromate de potassium $\left(\mathrm{K}_{2} \mathrm{Cr}_{2} \mathrm{O}_{7}\right)$, ont été collectées, pour lequel une fourchette de CE50-24 h variant entre $0,6-2,1 \mathrm{mg} \cdot \mathrm{L}^{-1}$ est une condition d'acceptation pour l'essai aigu de $D$. magna selon la norme ISO 6341.

Les moyennes des CE50s, ainsi que leurs écarts-types et coefficients de variation sont rapportées et discutées en détail, avec tableaux et figures à l'appui.

À partir de l'analyse des nombreuses données portant sur le contrôle de qualité du test aigu de $D$. magna, il est possible de conclure que :

(1) Quasiment tous les essais effectués avec les daphnies provenant de cultures de laboratoire ou de microbiotests Daphnia sont conformes à la norme ISO 6341 pour ce qui est des résultats générés avec le bichromate de potassium.

(2) Les moyennes de CE50-24 h rapportées pour le microbiotest Daphnia par différents laboratoires sont dans la fourchette des résultats de l'essai traditionnel et les coefficients de variation (entre 20-30 \%) sont semblables.

(3) La précision des tests de contrôle de qualité - qui témoigne de la variabilité sur une échelle de temps relativement longue pour chaque laboratoire - est équivalente pour les deux méthodes.

La revue, par la suite, fait état des études de comparaison de sensibilité intra-laboratoire réalisées avec les deux méthodes (traditionnelle et microbiotest) depuis 15 ans pour l'évaluation de produits chimiques et d'échantillons environnementaux. Provenant de laboratoires indépendants, les données démontrent des coefficients de corrélation situés entre 0,86 et 0,98 , ce qui confirme la sensibilité équivalente des tests avec animaux d'élevage et ceux provenant des œufs de durée de $D$. magna.

La troisième partie de la revue offre un constat de l'analyse des données de tests d'intercalibration lancés depuis 2002 par différents pays avec le test aigu $D$. magna et dans lesquels certains laboratoires ont effectué leurs essais avec des organismes d'élevage et d'autres avec le microbiotest Daphnia.

Les conclusions émanant des tests d'intercalibration confirment que la sensibilité des daphnies issues d'œufs de dormance est comparable à celle des animaux d'élevage et que dans la plupart des cas, la précision du microbiotest Daphnia est même supérieure à celle des essais réalisés en conditions d'élevage.

Enfin, la revue discute des différences possibles de sensibilité de daphnies d'œufs de dormance provenant de souches différentes de $D$. magna. 
De ces études, il apparait qu'aucune différence significative n'est démontrée entre les CE50s issues d'essais de daphnies éclos des œufs de dormance produits par des souches différentes de $D$. magna et celles mesurées avec des animaux d'élevage.

Les avantages incontestables de l'essai entrepris avec des daphnies d'œufs de dormance (qui exclut le maintien de cultures) sur celui faisant appel aux animaux d'élevage, ont contribué à l'emploi international du microbiotest Daphnia à des fins de recherche et de surveillance.

Présentement employé dans plusieurs pays tant à des fins de réglementation de la toxicité que de recherches en écotoxicologie, il est estimé que quelque 10000 essais aigus vis-à-vis de D. magna sont entrepris sur une base annuelle avec le microbiotest Daphnia.

L'emploi d'œufs de dormance a déjà été reconnu par des instances normatives internationales à des fins d'études de toxicité.

La norme ISO 20665 de 2008 décrivant l'essai de toxicité chronique vis-à-vis de Ceriodaphnia dubia, par exemple, ainsi que la norme ISO 20666 de 2008 décrivant celui de $48 \mathrm{~h}$ conduit avec Brachionus calyciflorus précisent que ces tests peuvent être appliqués avec des organismes éclos d'œufs cryptobiotiques.

À la lumière de l'envergure des données scientifiques validées et rapportées dans cette revue, lesquelles sont logiquement appuyées par les normes ISO mentionnées ci-dessus, les auteurs s'accordent unanimement à recommander l'emploi de daphnies provenant d'œufs de dormance pour l'entreprise d'essais normatifs nationaux et internationaux au même titre que les daphnies provenant d'élevage en laboratoire.

\section{INTRODUCTION}

The need to protect aquatic and terrestrial biota on our planet from uncontrolled releases of pollutants has gradually triggered over the past five decades the development of methods capable of evaluating the adverse effects of chemicals and of solid/liquid wastes.

Acute and chronic toxicity tests conducted with various test species belonging to different phylogenetic levels are now available and several testing protocols are now well standardised.

A very popular bioassay used internationally for toxicity screening of chemical compounds and the monitoring of industrial effluents is undoubtedly the acute toxicity test with freshwater Daphnids, particularly with Daphnia magna and Daphnia pulex. Rationale for use of these two test species is their broad distribution in a wide range of habitats, their relatively short life cycle and the fact that they are relatively easy to culture and maintain in the laboratory.

Test protocols for undertaking acute toxicity tests with $D$. magna and $D$. pulex have been described in scientific literature as of the 1960s and standard test procedures with these two species have since been endorsed by several national and international organisations involved in environmental protection.

A recent comprehensive review on acute and chronic toxicity tests conducted with Daphnia sp. by Jonczyk and Gilron (2005) reports the major international and national organisations which prescribe Daphnia assays for various types of applications.

Examination of the detailed characteristics of the acute Daphnia tests prescribed by these organisations reveals that culturing and testing conditions of test organisms differ (in some cases substantially) from one method to another.

As emphasized by Jonczyk and Gilron (2005) and the many scientific studies they refer to, abiotic (temperature, light, $\mathrm{pH}$, chemical composition of the water) as well as biotic conditions (feeding, strain of test organism) have a significant influence on the test results and their variability. 
Besides differences in abiotic and biotic factors, the assessment endpoint selected for evaluation of the toxic impact is also different in the prescribed methodologies. International organisations such as ISO and OECD have adopted the "immobility" criterion, i.e. the inability of the test organisms to resume swimming within $15 \mathrm{~s}$ after gentle agitation, whereas organisations in North America (US EPA, Environment Canada, ASTM) eventually selected "lethality" as a second assessment endpoint for effect measurement. Mortality of test organisms is actually the criterion mostly used for acute toxicity tests with invertebrates and fish. Asian and Australian countries presently mainly use LC50s to express effects for acute Daphnia assays.

As shown by the extensive data bases on acute effects of chemicals on Daphnids, LC50s and EC50s, however, do not differ markedly and this probably explains why the Commission of the European Communities in the section on acute toxicity testing for Daphnia in Directive 92/69/EEC specifies that "the Directive requirement for the LC50 for Daphnia is considered to be fulfilled by the determination of the EC50 as described in this method" (Commission of the European Communities, 1992).

Another difference between methodologies for acute Daphnia assays relates to time of exposure.

At the international level, ISO standard 6341:1996 "Determination of the inhibition of the mobility of Daphnia magna straus (Cladocera, Crustacea) - Acute toxicity test" (ISO, 1996) prescribes determination of the $24 \mathrm{~h}$ EC50 and "where appropriate" the $48 \mathrm{~h}$ EC50.

OECD Guideline 202 issued in 1984 (OECD, 1984), was originally also based on a $24 \mathrm{~h}$ exposure period "which could be extended to $48 \mathrm{~h}$ if desired". The 2004 revision of this guideline (OECD, 2004) now prescribes that the degree of immobilisation must be recorded at both $24 \mathrm{~h}$ and $48 \mathrm{~h}$. The test method published by the Commission of the European Communities (1992) indicates that the test duration should "preferably" be one of $48 \mathrm{~h}$.

For standard test procedures applied at the national level, the exposure period indicated in the US EPA test method 2021.0 on acute $D$. magna assays with effluents and receiving waters (US EPA, 2001) indicates 24 h, 48 h or 96 h "as available options", whereas in the EPS1/RM/11 method prescribed by Environment Canada the exposure time is strictly one of $48 \mathrm{~h}$ (Environment Canada, 1996).

\section{TEST SENSITIVITY AND TEST PRECISION}

As emphasized in all guidelines and norms on standard acute toxicity tests, "sensitivity" and "precision" are the two major key factors for the credibility of the test results at the intralaboratory as well as at the inter-laboratory level.

Both the sensitivity and the precision of the assays are intrinsically dependent on the experimental abiotic and biotic factors which are selected for the culturing and the testing, also including the $D$. magna strain and the type and the nutritional value of the algal food. In their recent review on acute and chronic toxicity testing with Daphnia species, Jonczyk and Gilron (2005) discuss in detail a number of factors "capable of influencing performance of test organism and test results".

The first aim of the present review was to collect all literature information as well as data from various laboratories, related to sensitivity and precision of the acute toxicity test with D. magna.

As indicated in many publications on the biology of daphnids, there is worldwide a multitude of $D$. magna strains, each of which has its own ecological (and genetic) characteristics.

Baird et al. (1990) showed in this regard that different $D$. magna clones have different sensitivities to particular toxicants and in an earlier paper (Baird et al., 1989), the authors mentioned that the variability of Daphnia bioassays can be partitioned into three components: genetic, environmental and interaction between genotype and environment. 
The "genetic" influence on the sensitivity of acute $D$. magna tests is, however, in practice not taken very much into account. Indeed, D. magna strains used for stock culturing in ecotoxicological laboratories mostly originate from different sources and their historical origin and characteristics are mostly not even known.

The "environmental" aspects mentioned by Baird et al. (1989) with regard to their influence on the sensitivity of the assays, refer to all the abiotic and biotic factors involved in the culturing and maintenance of the live stocks of test organisms, as well as to the abiotic factors of testing conditions as already mentioned above.

The influence of these factors on test results is not exclusive for Daphnia tests but inherent to all ecotoxicological assays. Guidelines and norms of toxicity tests therefore describe (with or without detail) the culturing and test conditions, as well as the precautions which must be taken to minimise variability in sensitivity which could be due to these aspects.

One of these factors is the age of test organisms at the start of the tests. Most standard test protocols prescribe that the acute assays have to be performed with young Daphnids less than $24 \mathrm{~h}$ old at the start of the test. Many methods in addition also indicate that the neonates should preferably not be "first brood" progeny. ISO standard 6341 (ISO, 1996) even imposes that the test organisms should be "at least third generation" offspring.

A simple way to get an estimate of the health and the sensitivity of test organisms is to perform tests on reference toxicants. All standard ecotoxicological methods to date therefore advise, and some even impose, that "control" assays be performed on reference toxicants in the same manner and under the same conditions as the assays on the samples under investigation.

Extensive fundamental research has been performed over the years in many laboratories worldwide on the sensitivity of $D$. magna to a variety of inorganic and organic chemicals and several studies were conducted in the 1970s and 1980s on the selection of particular compounds for reference toxicity tests. Yet, as indicated by Jop et al. (1986) in their study on the use of hexavalent chromium as a reference toxicant in aquatic toxicity tests, several reference toxicants had already been proposed at that time, but none had so far been universally accepted.

In 1990 Environment Canada issued a "Guidance document on control of toxicity test precision using reference toxicants" (Environment Canada, 1990) in which nine criteria were proposed for the selection of particular reference compounds.

From the four chemicals which were originally earmarked as most appropriate for the acute Daphnia assay, three compounds were eventually retained in the amended version (1996) of the standard acute lethality test (Environment Canada, 1996): sodium chloride, zinc sulphate and potassium dichromate.

As indicated in many publications, reference testing on particular compounds also serves as the best tool for determining the "precision" of toxicity tests, i.e. the closeness of agreement between test results.

The degree of precision of assays is usually expressed as the coefficient of variation (CV) of the test results (which is expressed as a percentage) and which can be determined at two levels: the intra-laboratory level to assess "repeatability" of the assays and the interlaboratory level to determine "reproducibility".

Confusion, however, sometimes occurs with regard to the interpretation of the precision of the tests at the intra-laboratory level. A distinction has indeed to be made between results of assays performed in a particular laboratory in several replicates, or repeated in a very short period of time, and that of "quality control" tests which reflect "long term" intra-laboratory performance capability.

In their study on the precision of $D$. magna static acute tests, Gersich et al. (1986) e.g. report greater variability when the assays are carried out on different occasions, compared with simultaneous tests. 


\section{INTRA- AND INTER-LABORATORY PRECISION OF THE ACUTE DAPHNIA MAGNA TEST}

One of the very first studies on the precision of the acute $D$. magna toxicity test is the ring test organised in April 1978 (Study D8369) by the Commission of the European Communities (1979). The exercise made use of the "draft standard" which is at the basis of ISO standard 6341 "Water Quality - Determination of the mobility of Daphnia magna Straus (Cladocera, Crustacea) - Acute toxicity test" which was subsequently issued by the ISO in 1982 with a revision in 1996 (ISO, 1996).

Five chemicals were selected for the inter-laboratory exercise: potassium dichromate, tetrapropylbenzene sulphonic acid (T.P.B.S. $N^{\circ} 1$ ), sodium tetrapropylbenzenesulphonate (T.P.B.S. $\mathrm{N}^{\circ} 2$ ), potassium salt of 2,4,5 trichlorophenoxyacetate and dichlobenyl. Each participating laboratory was requested to submit results for three repeated assays on each of the test substances. Eventually data from 48 laboratories of nine European countries and the USA were taken into consideration for calculation of the mean $24 \mathrm{~h}$ EC50 and the repeatability/reproducibility coefficients.

The results of this very first ringtest, are summarized in Table I of ISO 6341, except for dichlobenyl, and indicate that the CVs for the test repeatability range from 5 to $14 \%$, and from 30 to $50 \%$ for the test reproducibility.

It should, however, be mentioned that for potassium dichromate, Table I of ISO 6341, does not express the data from the Commission of the European Communities ring test. Indeed the report of this exercise indicates a mean $24 \mathrm{~h} \mathrm{EC50}$ of $1.46 \mathrm{mg} \cdot \mathrm{L}^{-1}$ for the 129 test data, with an intra-laboratory CV of $14 \%$ and an inter-laboratory variability CV of $39 \%$.

The different numbers which are given in Table I of ISO 6341 for potassium dichromate are, however, not erroneous... Indeed, during the course of the years following the Commission of the European Communities ring test, potassium dichromate was gradually selected as the "preferred" reference compound.

ISO therefore issued a call in 1994 to its member countries asking them to provide data of their own in-house tests performed on this reference chemical since the time of the ringtest in 1978. The data in Table I of ISO 6341 in fact express the mean $24 \mathrm{~h}$ EC50 $\left(1.12 \mathrm{mg} \cdot \mathrm{L}^{-1}\right)$ for 1697 tests on potassium dichromate collected from 36 laboratories, and from which a $5 \%$ CV was calculated for the repeatability and 50\% CV for the reproducibility.

For the sake of completeness it can be mentioned that the Commission of the European Communities ringtest on the acute $D$. magna assay was almost concurrent with a (small) intra- and inter-laboratory study on the precision of the short-term $D$. magna test that had been carried out in the Netherlands with 15 inorganic and organic chemicals (Canton and Adema, 1978). According to the authors there was very little difference between the duplicates of one single short-term test, but the replication of the test in each of the two participating laboratories gives more divergent values.

Subsequent to the first major ringtest launched by the Commission of the European Communities, a substantial number of intra- and inter-laboratory studies dealing with the precision of Daphnia assays have been performed by various laboratories and organisations in different countries.

In an attempt to evaluate the precision of effluent toxicity tests, Parkhurst et al. (1992) issued an extensive review paper on performance characteristics of effluent toxicity tests. For this impressive review they compiled, summarized and evaluated published and unpublished data from 23 intra- and inter-laboratory studies carried out in the 1980s in the USA on the variability of acute and chronic toxicity tests performed with several test species on pure chemicals and on effluents.

Characteristics and major data on the intra- and inter-laboratory studies dealing specifically with acute $D$. magna tests compiled by Parkhurst et al. (1992) have been taken from the compilation review and are presented in Tables I and II respectively. 


\section{Table I}

Intra-laboratory variability of test results of the acute D. magna test for pure chemicals and effluents (cited from Parkhurst et al., 1992).

Tableau I

Variabilité intra-laboratoire des résultats de tests de toxicité aiguë vis-à-vis de $D$. magna sur des produits chimiques et des effluents (données de Parkhurst et al., 1992).

\begin{tabular}{|l|c|c|c|c|c|c|c|}
\hline & $\begin{array}{c}\text { Number } \\
\text { of } \\
\text { studies }\end{array}$ & $\begin{array}{c}\text { Total } \\
\text { number of } \\
\text { participating } \\
\text { laboratories }\end{array}$ & $\begin{array}{c}\text { Total number } \\
\text { of chemicals } \\
\text { or effluents } \\
\text { analysed }\end{array}$ & $\begin{array}{c}\text { Number } \\
\text { of tests } \\
\text { performed in } \\
\text { each laboratory }\end{array}$ & $\begin{array}{c}\text { Total } \\
\text { number } \\
\text { of tests } \\
\text { performed }\end{array}$ & $\begin{array}{c}\text { Test } \\
\text { duration }\end{array}$ & $\begin{array}{c}\text { Coefficient } \\
\text { of variation } \\
(\%)\end{array}$ \\
\hline $\begin{array}{l}\text { Pure } \\
\text { chemicals }\end{array}$ & 2 & 4 & 3 & $2-13$ & 53 & $48 \mathrm{~h}$ & $3-72$ \\
\hline Effluents & 3 & 15 & 7 & $2-3$ & 71 & 24 or $48 \mathrm{~h}$ & $0-49$ \\
\hline
\end{tabular}

\section{Table II}

Inter-laboratory variability of test results of the acute D. magna test for pure chemicals and effluents (cited from Parkhurst et al., 1992).

\section{Tableau II}

Variabilité inter-laboratoire des résultats de tests de toxicité aiguë vis-à-vis de $D$. magna sur des produits chimiques et des effluents (données de Parkhurst et al.,

\begin{tabular}{|l|c|c|c|c|c|c|}
\hline & $\begin{array}{c}\text { Number } \\
\text { of } \\
\text { exercises }\end{array}$ & $\begin{array}{c}\text { Number of } \\
\text { laboratories } \\
\text { in each } \\
\text { exercise }\end{array}$ & $\begin{array}{c}\text { Total number } \\
\text { of laboratories } \\
\text { in all exercises }\end{array}$ & $\begin{array}{c}\text { Total number } \\
\text { of chemicals } \\
\text { or effluents } \\
\text { analysed }\end{array}$ & $\begin{array}{c}\text { Test } \\
\text { duration }\end{array}$ & $\begin{array}{c}\text { Coefficient } \\
\text { of variation } \\
(\%)\end{array}$ \\
\hline Pure chemicals & 2 & $3-5$ & 13 & 3 & $48 \mathrm{~h}$ & $39-143$ \\
\hline Effluents & 3 & $2-9$ & 33 & 7 & 24 or $48 \mathrm{~h}$ & $1-110$ \\
\hline
\end{tabular}

Although according to Parkhurst et al. (1992) the most extensive data set available for the test variability of acute tests is for assays with Daphnias (D. magna, D. pulex and Ceriodaphnia dubia), Tables I and II show that the number of intra- and inter-laboratory studies dealing specifically with acute $D$. magna assays is in fact limited. The data indeed originate from only five studies (Broderius, 1983; Buikema, 1983; Grothe and Kimerle, 1985; Lewis and Weber, 1985; Rue et al., 1988), in which only a limited number of laboratories participated with a limited number of chemicals or effluents.

One of the most striking facts of this data compilation is that although all the assays were carried out according to the "standard" prescriptions of the US EPA manuals for toxicity testing, both tables indicate that there is a very broad range between the lowest and the highest variation coefficients for the LC50s or EC50s; the minimum CVs are indeed as low as $0-3 \%$ and the maxima are up to $72-143 \%$. A detailed look at the tables in the publication of Parkhurst et al. (1992) shows that the "magnitude" of the CVs is related to the nature of the chemical compounds used for the tests and that for both the intra- and inter-laboratory studies the highest CVs are associated with the "most toxic" chemicals. This could be partly due to the greater instability of the very low concentrations of these toxic chemicals than higher concentrations of less toxic chemicals.

This statement also confirms the outcome of an inter-laboratory study on the acute toxicity of three chemicals on D. magna published by Lewis and Horning (1991) in which the variation coefficients for 10 repeated assays were $14.3 \%$ for sodium pentachlorophenate, $27.9 \%$ for sodium dodecylsulphate and $49.2 \%$ for cadmium chloride.

In the 1980s Environment Canada (Atlantic Region) conducted an inter-laboratory comparison study on the acute toxicity of potassium dichromate to D. magna (Parker, 1983). 
Unfortunately no meaningful conclusions can be drawn from this study since the participating three laboratories used different test conditions (organisms of different age and different exposure times ranging from 24 to $96 \mathrm{~h}$ ).

An interesting overview paper on test precison in relation to aquatic toxicity tests for the control of effluent discharges in the UK was published by Whitehouse et al. (1996).

This study addresses in detail the precision of the acute $D$. magna test and compiled a.o. data from six intra- and three inter-laboratory studies performed on single chemicals in the 1970s and the 1980s.

With regard to repeatability, the authors calculated that for 47 intra-laboratory test results, the CV's for three quarters of the assays were below 33\%; for the reproducibility, the $75 \%$ ile for the distribution of the CV's for 18 inter-laboratory data was $46 \%$.

Both the intra- and inter-laboratory variability of acute $D$. magna tests are also addressed in detail in the extensive Guidance Document for acute lethality testing of metal mining effluents (Report E1191) prepared for the Standard Development Branch of the Ontario Ministry of the Environment in Canada (Ontario Ministry of the Environment, 2002). From test data provided by nine laboratories from both the private and public sectors, within-laboratory and betweenlaboratory variability were calculated for acute $D$. magna tests; the corresponding CVs were $4.6 \%$ and $8.7 \%$ for sodium chloride and $27.3 \%$ and $33.3 \%$ for zinc chloride.

One of the conclusions reported in the Guidance Document on the variability aspects of acute $D$. magna assays confirms the statement made above from the data compilation by Parkhurst et al. (1992) namely that intra-laboratory test results indicate that the choice of toxicant seems to significantly influence the magnitude of the variability.

It is interesting to note that at the international level, ISO, OECD and the European Community apparently have a different opinion with regard to the "validity" of $D$. magna acute assay results with regard to intra-laboratory precision.

ISO norm 6341 (ISO, 1996) indeed indicates that test organism sensitivity and test procedure conformity must be determined periodically on the reference chemical potassium dichromate, and that the $24 \mathrm{~h}$ EC50 of the reference test must be mentioned in the test report.

Originally the ISO standard indicated that the $24 \mathrm{~h}$ EC50 for potassium dichromate had to be in the range $0.6-1.7 \mathrm{mg} \cdot \mathrm{L}^{-1}$ (ISO, 1996) but in 1998, a Technical Corrigendum was issued, broadening the maximum $24 \mathrm{~h}$ EC50 acceptability to $2.1 \mathrm{mg} \cdot \mathrm{L}^{-1}$.

In the updated 2004 version of the Daphnia sp. acute immobilisation test, OECD only specifies that a reference substance "may be tested" as a means of assuring that the test conditions are reliable and that the toxicants used in international ringtests are recommended for this purpose (with reference to the ring test carried out in 1978 by the Commission of the European Communities, and Table I of ISO 6341). The test report shall only indicate the results and the date of the test performed with a reference substance "if available"...

Commission Directive 92/69/EEC on the acute toxicity test on Daphnia (Commission of the European Communities, 1992) mentions that a reference substance "may be tested as a means of demonstrating that under the laboratory test conditions the sensitivity of the test species has not changed significantly". Reference is given in this regard to the results of the ring test conducted in 1978 by this Commission on the compounds used during this exercise. The test report shall "if possible" include the results obtained on a reference substance...

In a manner similar to international organisations, national organisations prescribing acute Daphnia tests each have their own rules with regard to acceptability of assay results that may or may not include guidelines on reference chemicals.

\section{DEVELOPMENT OF ALTERNATIVE TEST METHODS}

All information and literature detailed above deal specifically with acute Daphnia assays based on the use of test organisms obtained from laboratory cultures.

During the last three decades, technologies have, however, been developed which make bioassays independent of year-round culturing/maintenance of stocks of live test organisms. 
During the course of these investigations a "culture/maintenance free" assay was also developed for acute toxicity tests with $D$. magna.

The second part of this review is therefore dedicated to the comparison of the "traditional" acute $D$. magna assays which make use of test organisms from laboratory cultures with the (relatively recent) technology in which assays are based on neonates hatched from dormant eggs (ephippia).

This comparison will specifically focus on the sensitivity and the precision of the alternative assay, in comparison to the conventional test with organisms from laboratory cultures.

For the sake of simplicity, assays performed with $D$. magna neonates taken from laboratory cultures will be referred to as "lab culture tests" whereas those based on $D$. magna neonates hatched from dormant eggs will be named "Daphnia microbiotests".

\section{CULTURING AND AVAILABILITY OF TEST ORGANISMS}

Toxicity tests are by definition based on the use of live test biota, which either have to be obtained from reliable sources or which, as is mostly the case, are cultured and maintained in the laboratory where the assays are performed.

The multiple technical and biological aspects inherent in culturing and maintenance of laboratory stock of Daphnias are addressed in detail in the recent review by Jonczyk and Gilron (2005). From this review it can be concluded that the expression "relatively easy to culture and maintain in the laboratory" is in reality fraught with a multitude of factors which have all to be taken into consideration to obtain healthy Daphnias in sufficient numbers for performance of reliable fit for purpose toxicity tests.

Despite the merits of this most valuable publication, the authors do not address the "economic" aspects involved in stock culturing of test organisms related to costs inherent to the year-round availability and culture maintenance of the biological material.

The latter aspect was actually the subject of a study sponsored in 1986 by the Commission of the European Communities that sought to evaluate the costs of five major ecotoxicological tests including the acute $D$. magna test (Persoone and Van de Vel, 1987). From data provided by about 40 ecotoxicological laboratories from various European countries it appeared that for most laboratories the majority of the costs of bioassays were related to the (daily) culturing and maintenance of stocks of live test organisms rather than to conducting the actual test.

The dependence on live test material and the inherent costs of stock culturing and maintenance of test organisms to date still restrict toxicity testing worldwide to a limited number of highly specialised laboratories. Even in these laboratories availability of sufficient numbers of test organisms very often impedes routine testing and monitoring of large numbers of samples.

This fundamental burden for toxicity tests has triggered investigations in the early 1980s aiming at finding solutions to this major problem.

These studies eventually brought forward the new concept of "microbiotests" and "smallscale toxicity tests", the attractive characteristics of which are detailed in a review paper by Blaise (1991).

\section{MICROBIOTESTS}

The very first success in small-scale toxicity tests bypassing the burden of keeping live stocks was the "bacterial luminescence inhibition test" with Vibrio fischeri freeze-dried marine bacteria (Bulich and Isenberg, 1980).

This rapid assay presently used worldwide in hundreds of laboratories for toxicity screening of aquatic samples became very popular because of the year-round commercial availability of the biological material "in a stable inert form". 
The concept of "dormant" (cryptobiotic) biological material from which test organisms can be obtained independently of stock culturing, triggered intensive research in the Laboratory for Biological Research in Aquatic Pollution (now renamed Laboratory for Environmental Toxicology) at the Ghent University in Belgium (Persoone, 1992). This research initiative sought to achieve controlled production of dormant or immobilised stages of eukaryotic organisms that could be stored for long periods of time and from which the test species could be hatched (or de-immobilised) at the time of performance of toxicity testing.

Over the last 20 years a whole suite of small-scale acute and short-chronic "culture/maintenance free" microbiotests has been developed in the above mentioned laboratory, with test species representing several phylogenetic groups: micro-algae, protozoa, rotifers, crustaceans and higher plants (Janssen, 1998; Persoone, 2001).

These assays are to date available commercially under the generic name "Toxkits", one of which is the Daphtoxkit $F$ magna microbiotest which makes use of dormant eggs of D. magna (Persoone, 1998).

Cryptobiotic eggs are produced by $D$. magna in nature and occasionally also occur in laboratory cultures under specific environmental conditions. These eggs, resulting from sexual reproduction, are encapsulated in a protective carapace called ephippium, and can remain "dormant" (and viable) for many years. Only when triggered by specific stimuli does the embryonic development resume and culminate in the hatching of neonates.

Once all the factors involved in the controlled production of the dormant eggs had been fully investigated and optimised, a test procedure was developed and validated for a microbiotest with $D$. magna hatched from dormant eggs. The operational procedure of the Daphtoxkit $F$ magna assay was streamlined such that it is identical to the test methodology prescribed by the ISO (1996) and OECD (2004) for acute testing with this crustacean test species, with the exception that the test organisms are obtained by hatching of dormant eggs, instead of being taken from laboratory stock cultures.

Because of their independence of the stock culturing/maintenance burden and the miniaturization of the assays in practical and user-friendly kits, Toxkit microbiotests, and in particular Daphtoxkits, are presently used by many laboratories worldwide for research as well as for toxicity monitoring purposes and data and findings generated for a multitude of applications have already been published in many scientific periodicals.

Notwithstanding the advantages of the microbiotest technology over that of the "traditional" test methodology, the sensitivity and the degree of precision of the Daphnia microbiotest need to be evaluated and compared to that of the conventional acute $D$. magna assay (lab culture test).

In this respect, an effort has therefore been made to collect as much information as possible on quality control tests and proficiency testing on the acute $D$. magna assay performed with the two types of neonates (from lab cultures or from dormant eggs). In addition information was searched on comparative studies for sensitivity and precision of the respective assays at the intra- and inter-laboratory levels. Finally data were also collected on the sensitivity and the precision of acute tests performed with neonates hatched from dormant eggs from different $D$. magna strains.

The sections below report the information and the data which could be gathered, and the discussions and conclusions which could be drawn from the comparisons.

\section{PRECISION OF THE ACUTE DAPHNIA MAGNA TOXICITY TEST WITH ORGANISMS FROM LABORATORY CULTURES OR HATCHED FROM DORMANT EGGS}

\section{> QUALITY CONTROL TESTING}

Many laboratories in different countries regularly perform in-house quality control (QC) tests on the $D$. magna assay with the reference chemical potassium dichromate, as recommended by national and international organisations dealing with standard toxicity tests. During the last 
Table III

Quality control tests on potassium dichromate with Daphnias from laboratory stock cultures.

Tableau III

Tests de contrôle de qualité sur le bichromate de potassium avec des daphnies de cultures de laboratoire.

\begin{tabular}{|l|c|c|c|c|c|c|}
\hline Country & Organisation & Years & $\begin{array}{c}\text { Number } \\
\text { of tests }\end{array}$ & $\begin{array}{c}\text { Mean 24 h } \\
\text { EC50 } \\
\left(\mathrm{mg}^{-L^{-1}}\right)\end{array}$ & $\begin{array}{c}\text { CV } \\
(\%)\end{array}$ & $\begin{array}{c}\text { Range } \\
\text { of the EC50s } \\
\left(\mathrm{mg}^{-L^{-1}}\right)\end{array}$ \\
\hline $\begin{array}{l}\text { Belgium } \\
\text { (Wallonia) }\end{array}$ & Issep & $2001-2008$ & 183 & 1.43 & 20.8 & $0.67-2.31$ \\
\hline $\begin{array}{l}\text { Belgium } \\
\text { (Flanders) }\end{array}$ & Lisec & $1997-2005$ & 22 & 1.01 & 26.5 & $0.61-1.66$ \\
\hline $\begin{array}{l}\text { Belgium } \\
\text { (Flanders) }\end{array}$ & Vito & $2002-2008$ & 31 & 0.80 & 29.9 & $0.43-1.64$ \\
\hline $\begin{array}{l}\text { The } \\
\text { Netherlands }\end{array}$ & $\begin{array}{c}\text { Grontmij- } \\
\text { Aquasense }\end{array}$ & $1998-2008$ & 27 & 1.24 & 21.5 & $0.70-1.80$ \\
\hline France & Cemagref & $2004-2007$ & 33 & 0.97 & 18.7 & $0.62-1.25$ \\
\hline Slovenia & $\begin{array}{c}\text { National Institute } \\
\text { of Chemistry }\end{array}$ & $2002-2008$ & 33 & 1.10 & 20.3 & $0.67-1.56$ \\
\hline Hungary & $\begin{array}{c}\text { National Institute } \\
\text { of Envir. Health }\end{array}$ & $2002-2008$ & 22 & 1.27 & 18.0 & $1.00-1.60$ \\
\hline
\end{tabular}

decade several laboratories are now also routinely using Daphnia microbiotests for their QC tests with this reference compound.

For the purpose of this review and in order to compare the sensitivity and the precision of the Daphnia microbiotest with that of lab culture tests, a request was made to laboratories in several countries to provide data of their in-house assays with potassium dichromate performed with either of the two types of $D$. magna neonates.

Several laboratories (from Belgium, the Netherlands, France, Spain, Slovenia and Hungary) kindly sent us their QC data for lab culture tests and for Daphnia microbiotests. From these data the mean $24 \mathrm{~h} \mathrm{EC50s}$ and the variation coefficients were calculated and are reproduced in Tables III and IV. The tables also provide information on the number of tests, the period of performance of the assays and the range between the minimum and the maximum EC50 value reported by the respective laboratories.

With regard to test acceptability according to ISO 6341, Table III shows that in two of the five laboratories which carry out their assays with "lab cultures", the $0.6-2.1 \mathrm{mg} \cdot \mathrm{L}^{-1}$ limits were exceeded in some tests. Yet in one of these two laboratories, only eight of the 183 EC50s (i.e. less than $5 \%$ ) were above $2.1 \mathrm{mg} \cdot \mathrm{L}^{-1}$ and four of these eight EC50s only exceeded the ISO limit by less than $0.1 \mathrm{mg} \cdot \mathrm{L}^{-1}$. In the other laboratory, six of the $31 \mathrm{EC} 50 \mathrm{~s}$ were below the lower acceptability limit but according to information received from this organisation this was due to (temporary) problems with their stock cultures.

The data in Table IV for the more than 350 quality control Daphnia microbiotests show that they are all situated within the acceptability range set by ISO.

Tables III and IV also indicate that the mean $24 \mathrm{~h} \mathrm{EC50} \mathrm{values} \mathrm{range} \mathrm{from} 0.80$ to $1.43 \mathrm{mg} \cdot \mathrm{L}^{-1}$ for the lab culture tests versus 1.02 to $1.28 \mathrm{mg} \cdot \mathrm{L}^{-1}$ for the Daphnia microbiotests.

The mean $24 \mathrm{~h}$ EC50s for the QC tests from the different laboratories are also shown in Figure 1, with the corresponding standard deviations. The data are presented in order of increasing EC50s for the lab culture tests and the Daphnia microbiotests respectively. The additional bar on the left side of this figure is the mean $24 \mathrm{~h}$ EC50 $\left(1.12 \mathrm{mg} \cdot \mathrm{L}^{-1}\right)$ 


\section{Table IV}

Quality control tests on potassium dichromate with Daphnias hatched from dormant eggs.

Tableau IV

Tests de contrôle de qualité sur le bichromate de potassium avec des daphnies éclos d'œufs de dormance.

\begin{tabular}{|l|c|c|c|c|c|c|}
\hline Country & Organisation & Years & $\begin{array}{c}\text { Number } \\
\text { of tests }\end{array}$ & $\begin{array}{c}\text { Mean 24 h } \\
\text { EC50 } \\
\left({\mathrm{mg} \cdot \mathrm{L}^{-1}}^{-1}\right.\end{array}$ & $\begin{array}{c}\text { CV } \\
(\%)\end{array}$ & $\begin{array}{c}\text { Range } \\
\text { of the EC50s } \\
\left(\mathrm{mg}^{-1}\right)\end{array}$ \\
\hline $\begin{array}{l}\text { Belgium } \\
\text { (Wallonia) }\end{array}$ & $\begin{array}{c}\text { Institut Provincial } \\
\text { Hyg.-Bact. Mons }\end{array}$ & $2005-2008$ & 48 & 1.26 & 18.7 & $0.88-1.90$ \\
\hline $\begin{array}{l}\text { Belgium } \\
\text { (Flanders) }\end{array}$ & MicroBioTests Inc. & $2002-2008$ & 216 & 1.15 & 16.3 & $0.75-1.90$ \\
\hline Spain & Interlab & $1997-2008$ & 70 & 1.02 & 28.58 & $0.60-2.00$ \\
\hline Slovenia & $\begin{array}{l}\text { Institute of Public } \\
\text { Health Nova Gorica }\end{array}$ & $2004-2008$ & 55 & 1.28 & 17.82 & $0.79-1.74$ \\
\hline
\end{tabular}

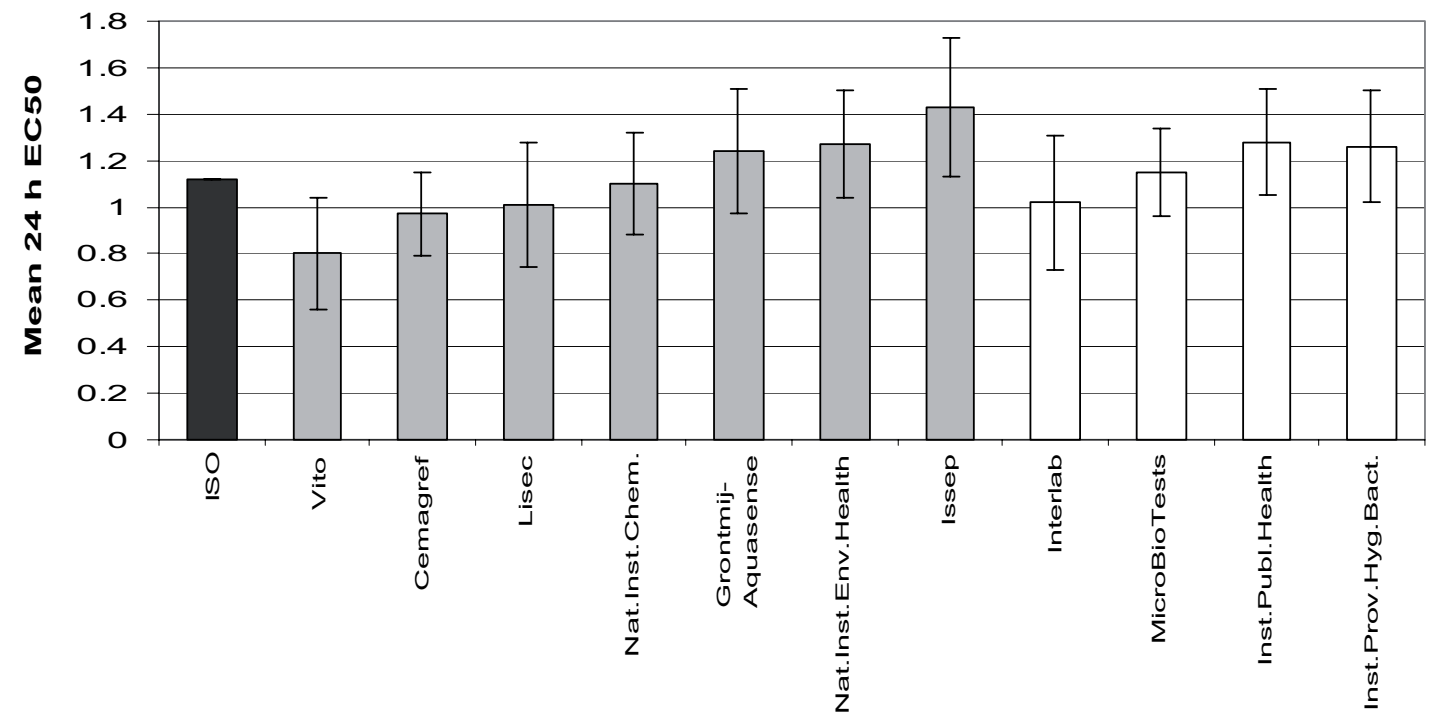

Lab culture tests

Daphnia microbiotests

\section{Figure 1}

Mean $24 \mathrm{~h}$ EC50s (in $\mathrm{mg} \cdot \mathrm{L}^{-1}$, with standard deviation) for quality control tests with potassium dichromate, with lab culture tests or Daphnia microbiotests.

\section{Figure 1}

Valeurs moyennes des CE50 $24 \mathrm{~h}$ (en $\mathrm{mg} \cdot \mathrm{L}^{-1}$, avec écart-type) de tests de contrôle de qualité sur le bichromate de potassium, avec des organismes de cultures de laboratoire ou des microbiotests Daphnia.

calculated by the ISO in 1994 for nearly 1700 reference tests carried out with potassium dichromate by 36 European laboratories. Figure 1 clearly shows that most of the mean EC50s are relatively close to the mean ISO value.

This figure also illustrates that the range between the mean EC50 values resulting from laboratories employing lab cultures is larger than that of laboratories performing Daphnia microbiotests. Besides different culturing conditions, the larger dispersion of the mean EC50s for the lab culture tests is probably also related to the different $D$. magna strains used 
in different laboratories, which is not the case with the Daphnia microbiotests. This aspect will be addressed in fuller detail below.

With regard to the precision of quality control tests, Tables III and IV show that the variation coefficients range from 18 to $30 \%$ for the lab culture tests and from 16 to $28 \%$ for the Daphnia microbiotests. The CV range is hence virtually identical for the two groups.

All data for the quality control tests with potassium dichromate reported and discussed above are for assays with an exposure period of $24 \mathrm{~h}$. The rationale for this is for most laboratories to provide the proof that their results are within the "acceptability range" $\left(0.6-2.1 \mathrm{mg} \cdot \mathrm{L}^{-1}\right)$ set by the ISO standard 6431 (1996) for "the check of the sensitivity of the test organisms and the conformity with the test procedure".

Laboratories seldom prolong their assays to $48 \mathrm{~h}$, although this test period is presently recommended, if not imposed, by national and international organisations for the acute D. magna assay.

From the 11 laboratories from which QC data were obtained, only two labs provided $48 \mathrm{~h}$ data for the assays with potassium dichromate. One of these two laboratories (the National Institute of Environmental Health in Budapest, Hungary) reported a mean $48 \mathrm{~h} \mathrm{EC50}$ of $1.09 \mathrm{mg} \cdot \mathrm{L}^{-1}$, with a CV of $23.7 \%$ for their 33 QC tests performed with organisms taken from lab cultures.

In parallel, MicroBioTests Inc. reported a mean $48 \mathrm{~h}$ EC50 of $0.80 \mathrm{mg} \cdot \mathrm{L}^{-1}$ for their $216 \mathrm{QC}$ tests with Daphnia microbiotests, and a mean CV of $14.3 \%$.

From facts and discussion given above, the following conclusions can be drawn on quality control tests for the acute $D$. magna assay:

(a) Virtually all the $24 \mathrm{~h}$ EC50 results of the nearly 750 quality control tests performed with either lab cultures or with Daphnia microbiotests are within the acceptability range set by the ISO standard 6341.

(b) The mean $24 \mathrm{~h}$ EC50s of Daphnia microbiotests are within the range of the mean EC50s of the lab culture tests, with similar variation coefficients.

(c) The precision - in terms of the long term in-house variability of the QC Daphnia microbiotests - is as good as that of the lab culture assays.

\section{> PROFICIENCY TESTING}

Several organisations such as the LGC Standards Proficiency Testing Group in the UK (Aquacheck), the England and Wales Environment Agency's Direct Toxicity Assessment Proficiency Schema (DTAPS), the Association Générale des laboratories d'analyse de l'environnement (Aglae) in France and the Canadian Association for Environmental Analytical Laboratories (CAEAL) regularly organise proficiency toxicity tests for individual laboratories to prove laboratory quality to accreditation bodies, customers and regulators. The results of some of these organisations are, however, mostly confidential and restricted to the participating laboratories.

Some information on proficiency tests for the acute $D$. magna assay generated by the CAEAL are, however, reported in the Guidance Document for acute lethality testing of metal mining effluents (Ontario Ministry of the Environment, 2002). This publication reports mean results from 33 laboratories for the period 1997 to 2000, and shows that the inter-laboratory variation coefficients for four coded samples ranged from 7.5 to $53.1 \%$.

Data from proficiency testing on the acute $D$. magna assay organised at the national level during recent years were also kindly provided by two institutes, in Slovenia and Hungary respectively, and are analysed in this review. The figures originate from the National Institute of Chemistry in Slovenia which organises such ringtests annually since 2002 and from the Environmental Protection and the Water Management Research Institute in Hungary which coordinates similar ringtests since 2004.

Toxicity data from the exercises in Hungary were generated with test organisms taken from laboratory cultures and are summarised in Table V. Those from Slovenia come from assays 
Table $V$

Acute D. magna ringtests performed in Hungary from 2004 to 2008 with potassium dichromate $\left(\mathrm{K}_{2} \mathrm{Cr}_{2} \mathrm{O}_{7}\right)$ with organisms taken from lab cultures.

Tableau $\mathrm{V}$

Exercices d'intercalibration du test aigu vis-à-vis de D. magna, organisés de 2004 à 2008 en Hongrie avec le bichromate de potassium $\left(\mathrm{K}_{2} \mathrm{Cr}_{2} \mathrm{O}_{7}\right)$, sur des organismes provenant de cultures de laboratoire.

\begin{tabular}{|l|c|c|c|c|}
\hline Year & $\begin{array}{c}\text { Number of } \\
\text { participants }\end{array}$ & $\begin{array}{c}\text { Mean 24 } \mathrm{h} \text { EC50 } \\
\left(\mathrm{mg} \cdot \mathrm{L}^{-1}\right)\end{array}$ & $\begin{array}{c}\text { Range of the } \\
\text { EC50s }\left(\mathrm{mg} \cdot \mathrm{L}^{-1}\right)\end{array}$ & $\begin{array}{c}\text { Inter-laboratory } \\
\text { CV }(\%)\end{array}$ \\
\hline $\mathbf{2 0 0 4}$ & 10 & 1.50 & $0.62-2.08$ & 33.3 \\
\hline $\mathbf{2 0 0 5 - 1}$ & 10 & 1.08 & $0.61-1.72$ & 46.0 \\
\hline $\mathbf{2 0 0 5 - 2}$ & 10 & 1.42 & $0.83-2.04$ & 34.3 \\
\hline $\mathbf{2 0 0 6 - 1}$ & 10 & 1.05 & $0.68-1.89$ & 40.9 \\
\hline $\mathbf{2 0 0 6 - 2}$ & 10 & 1.31 & $0.87-1.83$ & 29.4 \\
\hline $\mathbf{2 0 0 7 - 1}$ & 11 & 1.28 & $0.88-1.92$ & 23.9 \\
\hline $\mathbf{2 0 0 7 - 2}$ & 13 & 1.37 & $0.89-2.14$ & 28.4 \\
\hline $\mathbf{2 0 0 8 - 1}$ & 11 & 1.26 & $0.60-1.66$ & 31.8 \\
\hline $\mathbf{2 0 0 8 - 2}$ & 12 & 1.34 & $0.62-2.10$ & 32.4 \\
\hline
\end{tabular}

performed either with organisms from lab cultures or from Daphnia microbiotests. The latter data will therefore be dealt with in the next section of this review.

Ten to 13 Hungarian laboratories each year provided data which are situated in the "acceptability range" $\left(0.6-2.1 \mathrm{mg} \cdot \mathrm{L}^{-1}\right)$ of ISO 6341 and were hence taken into consideration for the calculation of the mean $24 \mathrm{~h}$ EC50s.

For all results of the above nine proficiency tests (97 data pieces) the mean $24 \mathrm{~h}$ EC50s range from 1.08 to $1.50 \mathrm{mg} \cdot \mathrm{L}^{-1}$, with variation coefficients ranging from 23.9 to $46.0 \%$.

\section{SENSITIVITY AND PRECISION COMPARISONS OF ACUTE} DAPHNIA MAGNA TESTS WITH ORGANISMS FROM LAB CULTURES AND WITH DAPHNIAS HATCHED FROM DORMANT EGGS

\section{> INTRA-LABORATORY COMPARISONS}

The very first comparative sensitivity study was made in 1998 in the laboratory at the Ghent University in Belgium where the technology of the Toxkit microbiotests was developed (Persoone, 1998). EC50s (24 and 48 h) were determined on 19 inorganic and organic chemicals and on nine effluents of the textile industry.

Similar comparative studies were performed during the next years on pure chemicals as well as on natural samples in laboratories in different countries. For example, such investigations have been made in Poland on nine pesticides (Fochtman, 2000), in Austria on 12 solid waste leachates (Latif and Zach, 2000), in Croatia on 30 household products (Ulm et al., 2000) and in the UK on 38 industrial effluents (Daniel et al., 2004).

An overview of these studies is reported in TTable $\mathrm{VI}$ which shows that all correlation coefficients $(r)$ of the $24 \mathrm{~h}$ EC50s were within the 0.86 to 0.98 range.

The correlation coefficients mentioned in Table $\mathrm{VI}$ and the statistical comparisons reported in the publications and the reports of the former studies all indicate that for the range of investigated toxicants, both types of $D$. magna neonates have a similar sensitivity for chemicals as well as for natural samples. 
Table VI

Intra-laboratory sensitivity comparison studies on the acute D. magna test performed with lab cultures or with Daphnia microbiotests.

Tableau VI

Études intra-laboratoire de comparaison de la sensibilité du test aigu vis-à-vis de $D$. magna, avec des organismes provenant de cultures de laboratoire ou de microbiotests Daphnia.

\begin{tabular}{|l|l|c|c|c|c|c|}
\hline Year & Country & Laboratory & Reference & Type of samples & $\begin{array}{c}\text { Number of } \\
\text { samples }\end{array}$ & $\begin{array}{c}\text { Correlation } \\
\text { coefficient }(r)\end{array}$ \\
\hline $\mathbf{1 9 9 8}$ & Belgium & Ghent University & $\begin{array}{c}\text { Persoone, } \\
1998\end{array}$ & $\begin{array}{c}\text { Inorganic and } \\
\text { organic } \\
\text { chemicals }\end{array}$ & 19 & 0.98 \\
\hline $\mathbf{1 9 9 8}$ & Belgium & Ghent University & $\begin{array}{c}\text { Persoone, } \\
1998\end{array}$ & $\begin{array}{c}\text { Effluents textile } \\
\text { industry }\end{array}$ & 9 & 0.88 \\
\hline $\mathbf{2 0 0 0}$ & Austria & $\begin{array}{c}\text { University of } \\
\text { Veterinary Medecine }\end{array}$ & $\begin{array}{c}\text { Latif and } \\
\text { Zach, 2000 }\end{array}$ & $\begin{array}{c}\text { Solid waste } \\
\text { leachates }\end{array}$ & 12 & 0.97 \\
\hline $\mathbf{2 0 0 0}$ & Croatia & $\begin{array}{c}\text { Zagreb Institute } \\
\text { of Public Health }\end{array}$ & $\begin{array}{c}\text { Ulm et al., } \\
2000\end{array}$ & $\begin{array}{c}\text { Household } \\
\text { products }\end{array}$ & 30 & 0.97 \\
\hline Kingdom & $\begin{array}{c}\text { Brixham } \\
\text { Environmental } \\
\text { Laboratory }\end{array}$ & $\begin{array}{c}\text { Daniel } \text { et al., } \\
2004\end{array}$ & $\begin{array}{c}\text { Industrial } \\
\text { effluents }\end{array}$ & 38 & 0.86 \\
\hline
\end{tabular}

These findings actually corroborate the findings reported above for the QC tests with the reference chemical potassium dichromate and prove that toxicity testing of unknown natural or artificial samples produces similar results with test organisms either from lab cultures or hatched from ephippias.

\section{>INTER-LABORATORY COMPARISONS}

Table VII lists recent inter-laboratory exercises dealing with or comprising acute $D$. magna assays performed with either lab culture tests or with Daphnia microbiotests, as well as their organisers and the type of samples on which the assays were performed.

As can be seen in Table VII, three ringtests specifically dealt with the acute $D$. magna toxicity test, whereas the two other exercises not only focused on comparison of the two types of $D$. magna assays, but also dealt with other toxicity tests.

Findings of these five ringtests are further discussed hereunder.

\section{Inter-laboratory sensitivity comparison of toxicity tests applied on industrial effluents, (Flanders, Belgium)}

A ringtest was performed in 2001 in Flanders, Belgium, under the supervision of the Flemish Environmental Agency VMM, comprising a battery of assays which had to be performed on effluents from various industries, taken at six different sampling periods during a one year period (Ruymen et al., 2003). In this study D. magna assays were performed on 48 samples collected from several industries involved in the production of organic chemicals or in waste treatment respectively. One laboratory carried out lab culture tests and a second laboratory performed Daphnia microbiotests. 
Table VII

Recent inter-laboratory sensitivity comparison studies on toxicity tests.

Tableau VII

Études récentes inter-laboratoire de comparaison de la sensibilité de tests de toxicité.

\begin{tabular}{|l|c|c|c|c|}
\hline Year & Country & Organiser & Type of samples & Type of tests \\
\hline $\mathbf{2 0 0 1}$ & Belgium & $\begin{array}{c}\text { Flanders Environmental } \\
\text { Agency }\end{array}$ & $\begin{array}{c}\text { Industrial } \\
\text { effluents }\end{array}$ & Several \\
\hline $\mathbf{2 0 0 2 - 2 0 0 8}$ & Slovenia & $\begin{array}{c}\text { National Institute } \\
\text { of Chemistry }\end{array}$ & $\begin{array}{c}\text { Simulated } \\
\text { wastewaters }\end{array}$ & $\begin{array}{c}\text { Acute } \\
\text { D. magna }\end{array}$ \\
\hline $\mathbf{2 0 0 3}$ & Italy & $\begin{array}{c}\text { Environmental Agency } \\
\text { APAT }\end{array}$ & Pure chemicals & $\begin{array}{c}\text { Acute } \\
\text { D. magna }\end{array}$ \\
\hline $\mathbf{2 0 0 6}$ & Italy & $\begin{array}{c}\text { Environmental Agency } \\
\text { APAT }\end{array}$ & $\begin{array}{c}\text { Pure chemicals } \\
\text { Acute } \\
\text { D. magna }\end{array}$ \\
\hline
\end{tabular}

Despite some problems with storage and delays in the distribution of the samples which biased some of the results, statistical comparison of the data pairs nevertheless revealed a good similitude of the $24 \mathrm{~h}$ EC50 data with both types of Daphnia neonates. The correlation coefficient $r$ for the 36 waste treatment samples from the industries dealing with waste treatment was indeed 0.98 , and the overall $r$ value for all data pairs was 0.93 (Persoone, 2004).

\section{Acute $D$. magna ringtests in Slovenia on simulated waste waters}

Since 2002 the National Institute of Chemistry (NIC) in Ljubljana, Slovenia has been organising yearly proficiency tests on a number of chemicals, but also on the acute $D$. magna assay. Each year some 20 laboratories from Slovenia and a few neighbouring countries participated in the ringtests with $D$. magna with either lab culture tests or with Daphnia microbiotests. The samples to be analysed were two types of "simulated waste waters" (T1 and T2) prepared and sent out by the NIC to participating laboratories which have to produce data for two repeated assays.

For reasons of homogeneity and stability the composition of the simulated waste waters was not disclosed to the participants, but the samples were in fact solutions of potassium dichromate and zinc acetate respectively in distilled water. Samples are prepared each year in a different concentration by the coordinating institute. For the sake of completion it should be mentioned that for the ringtest in 2006 , cadmium acetate was used instead of potassium dichromate for the simulated waste water $\mathrm{T} 1$.

The performance of each laboratory is calculated by the organisers with the aid of the internationally recommended Z-score, on the basis of the mean $24 \mathrm{~h}$ EC50s.

Detailed reports on these ringtests are provided each year by the NIC to the participating laboratories and several scientific papers have already been published on the outcome of the Daphnia inter-laboratory exercises (Cotman et al., 2003, 2007, 2009).

In the "overall" calculations reported in the annual NIC documents no distinction is made between the results of laboratories working with lab culture tests or with Daphnia microbiotests.

For the present review and in order to allow for a specific comparison of the results obtained with the two types of neonates, the NIC kindly, however, kindly provided all individual EC50s for the seven ringtests. 

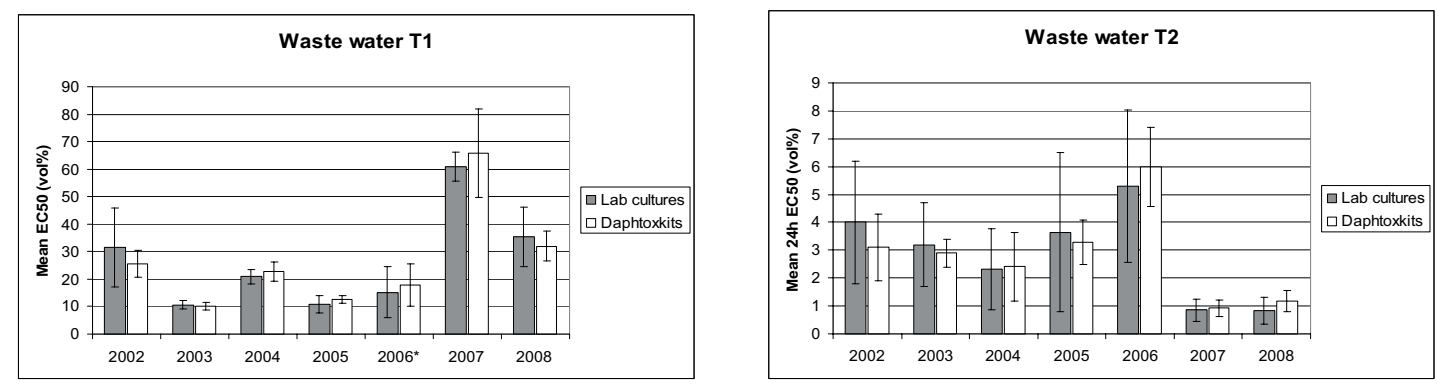

2006*: the simulated waste water T1 contained

cadmium acetate instead of potassium dichromate

\section{Figure 2}

Mean $24 h$ EC50s with standard deviation, for the lab culture tests and the Daphnia microbiotests, for seven Slovenian ringtests.

\section{Figure 2}

Valeurs moyennes des CE50 $24 \mathrm{~h}$, avec écart-type, de tests avec des organismes de cultures de laboratoire et des microbiotests Daphnia. Résultats de sept exercices d'intercalibration organisés en Slovénie.

From this information it appears that the number of participants using lab culture tests has decreased over the years, going from more than 10 to less than 5, whereas that of Daphnia microbiotests users in turn has increased from 8 to 13.

Figure 2 shows the yearly mean 24 h EC50s (expressed as volume \% of the original samples) with the corresponding standard deviations. Since the magnitude of the $50 \%$ effect values is different for the two types of wastewaters a different Y-scale is used for the two graphs.

It should be noted that the bars for each ringtest only aim at comparing the mean EC50s obtained with the two types of test organisms; the absolute values should not be compared for the successive ringtests since, as indicated above, the concentrations of the chemicals used in the wastewaters were indeed each year different. The mean EC50s therefore only express the dilution of the wastewater at which a $50 \%$ effect was obtained.

Statistical analysis was performed on all individual data, with the Student t-test or the MannWhitney $U$ test for normally and not normally distributed data respectively. Comparison of the data revealed that there are no significant differences in any of the seven ringtests between the mean EC50s from the lab culture assays versus those of the Daphnia microbiotests.

Figure 2 also shows that some standard deviations are quite high, in particular for the tests with zinc acetate (waste water T2).

In order to visualise the inter-laboratory precision of the Slovenian ringtests the corresponding variation coefficients are presented as bars in Figure 3. This graph clearly reflects the substantially higher inter-laboratory variability of the T2 wastewaters with both types of Daphnia neonates, but also highlights the higher CVs for the T1 wastewater in ringtest 2006, for which cadmium acetate had been used instead of potassium dichromate.

Figure 3 furthermore reveals that for most ringtests the CVs of the Daphnia microbiotests are lower than those of the lab culture tests. In several cases the difference between the CVs even exceeds $50 \%$.

Three major conclusions can be drawn from the Slovenian proficiency exercises on the D. magna acute toxicity bioassay:

(a) There is no statistical difference between the results obtained with organisms from lab cultures or hatched from dormant eggs.

(b) The inter-laboratory precision of the assays is strongly "chemical dependent" confirming the same statement already reported earlier. 

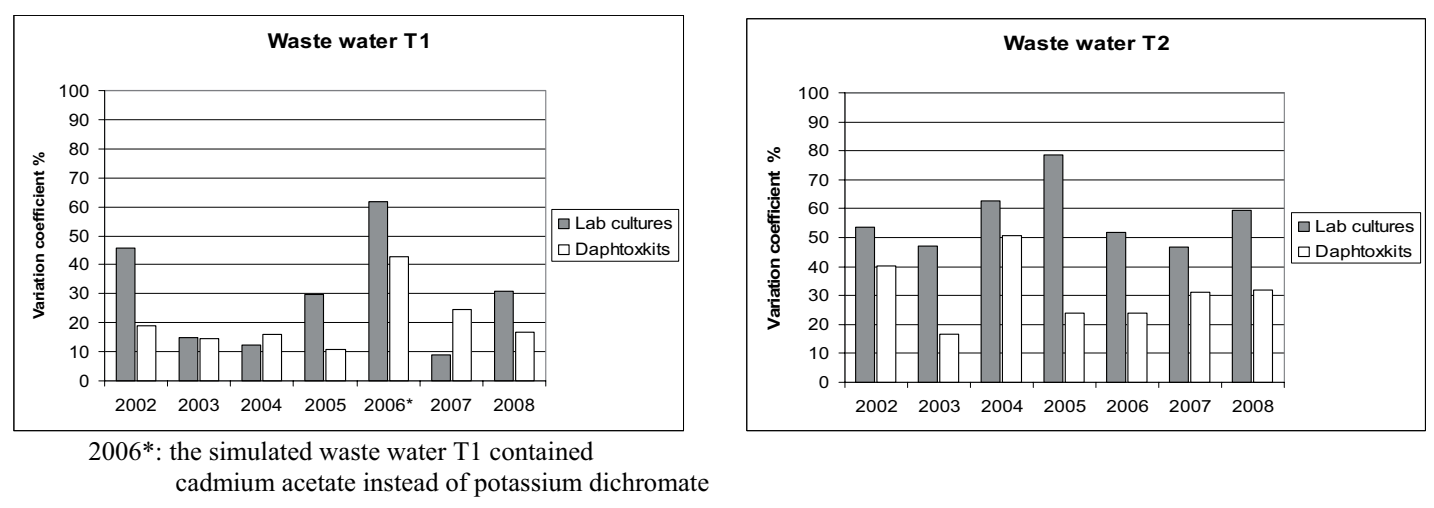

\section{Figure 3}

Coefficients of variation of the mean 24 h EC50s for the lab culture tests and the Daphnia microbiotests, for seven Slovenian ringtests.

\section{Figure 3 \\ Coefficients de variation des valeurs moyennes des CE50 $24 \mathrm{~h}$ de tests avec des organismes de cultures de laboratoire et des microbiotests Daphnia. Résultats de sept exercices d'intercalibration organisés en Slovénie.}

(c) The long term precision - in terms of the inter-laboratory reproducibility of the assays on the two test chemicals - is in most cases better for the Daphnia microbiotests than for the lab culture bioassays.

\section{Acute $D$. magna ringtests in Italy on pure chemicals}

In order to assess the intra- and inter-laboratory sensitivity and precision of the acute D. magna toxicity tests performed according to ISO 6341, the Italian Agency for environmental protection and technical services (APAT) organised an inter-laboratory comparison exercise in 2003 at the national level with the reference chemical potassium dichromate (Baudo et al., 2004). Participants could perform their assays either with lab cultured Daphnias or with the Daphnia microbiotest procedure and had to produce the results of three repeated assays.

The Italian ringtest was organised again by the APAT in 2005, with the same reference chemical as well as with potassium chloride $(\mathrm{KCl})$, the latter being sent to each laboratory as a "blind" toxicant.

The outcome of the two ringtests on potassium dichromate is presented and discussed in detail in the report by Baudo et al. (2006) submitted to the APAT.

For the present review the main data of these two comparative studies are summarized in Table VIII, which also includes data calculated by the ISO in 1994 for potassium dichromate as expressed in Table I of ISO 6341.

According to the organisers, all the individual EC50s from all the participating laboratories were within the acceptability range $\left(0.6-2.1 \mathrm{mg} \cdot \mathrm{L}^{-1}\right)$ prescribed by ISO 6341 for reference tests with potassium dichromate.

The mean $24 \mathrm{~h}$ EC50s for the lab culture tests and the Daphnia microbiotests given in Table VIII are identical for the 2003 ringtest $\left(1.08 \mathrm{mg} \cdot \mathrm{L}^{-1}\right)$ and quite similar for the 2005 exercise $\left(1.02-1.20 \mathrm{mg} \cdot \mathrm{L}^{-1}\right)$. Statistical data analysis has been performed for these ringtests and revealed that the mean EC50s are not significantly different from each other for the four sets of data.

It is also clear from Table VIII that the four mean EC50 values are quite close to the mean EC50 (1.12 $\left.\mathrm{mg} \cdot \mathrm{L}^{-1}\right)$ calculated by ISO in 1994 for about 1700 data pieces (ISO, 1996). 
Table VIII

Acute D. magna ringtests performed in Italy in 2003 and 2005 with potassium dichromate $\left(\mathrm{K}_{2} \mathrm{Cr}_{2} \mathrm{O}_{7}\right)$ (data from Baudo et al., 2006), and comparison with ISO data of 1994.

Tableau VIII

Exercices d'intercalibration du test aigu vis-à-vis de D. magna organisés en Italie en 2003 et 2005 avec le bichromate de potassium $\left(\mathrm{K}_{2} \mathrm{Cr}_{2} \mathrm{O}_{7}\right)$ (données de Baudo et al., 2006) et comparaison avec les données ISO de 1994

\begin{tabular}{|l|c|c|c|c|c|}
\hline & Year & $\begin{array}{c}\text { Number of } \\
\text { participants }\end{array}$ & $\begin{array}{c}\text { Mean } 24 \mathrm{~h} \\
\text { EC50 }\left(\mathrm{mg}^{-1}\right)\end{array}$ & $\begin{array}{c}\text { Intra-laboratory } \\
\text { CV }(\%)\end{array}$ & $\begin{array}{c}\text { Inter-laboratory } \\
\text { CV }(\%)\end{array}$ \\
\hline \multirow{2}{*}{ Lab cultures } & 2003 & 16 & 1.08 & 16.2 & 27.4 \\
\cline { 2 - 6 } & 2005 & 33 & 1.02 & 8.5 & 34.2 \\
\hline $\begin{array}{l}\text { Daphnia } \\
\text { microbiotests }\end{array}$ & 2003 & 56 & 1.08 & 17.1 & 24.5 \\
\cline { 2 - 6 } & 2005 & 40 & 1.20 & 9.9 & 23.9 \\
\hline ISO 6341 & 1994 & 36 & 1.12 & 5.0 & 50.0 \\
\hline
\end{tabular}

Table IX

Acute D. magna ringtest performed in Italy in 2005 with potassium chloride $(\mathrm{KCl})$ (data from Baudo et al., 2006).

Tableau IX

Exercice d'intercalibration sur le test aigu vis-à-vis de D. magna organisé en Italie en 2005 avec le chlorure de potassium (KCl) (données de Baudo et al., 2006).

\begin{tabular}{|l|c|c|c|c|}
\hline & $\begin{array}{c}\text { Number of } \\
\text { participants }\end{array}$ & $\begin{array}{c}\text { Mean 24 } \mathrm{h} \text { EC50 } \\
\left(\mathrm{mg} \cdot \mathrm{L}^{-1}\right)\end{array}$ & $\begin{array}{c}\text { Intra-laboratory } \\
\text { CV }(\%)\end{array}$ & $\begin{array}{c}\text { Inter-laboratory } \\
\text { CV (\%) }\end{array}$ \\
\hline Lab cultures & 32 & 817 & 5.3 & 43.1 \\
\hline Daphnia microbiotests & 42 & 765 & 6.6 & 20.8 \\
\hline
\end{tabular}

These two major Italian intercalibration studies thus also confirm the similar sensitivity of the two types of Daphnia neonates.

With regard to assay precision, it is interesting to note that in both Italian exercises the intralaboratory CV was similar in the two ringtests for both types of tests, but the absolute value was higher in the 2003 ringtest (16-17\%) than in the 2005 exercise (8-10\%). Whereas the inter-laboratory precision was also similar for the 2003 exercise for the two types of tests (27 and 24\%), it remained virtually the same for the Daphnia microbiotests in the 2005 ringtest but was substantially poorer (34\%) for the tests with lab cultured organisms.

The intra-laboratory CVs for the two ringtests are higher than the intra lab CV calculated by the ISO for data collected in 1994, but the inter-laboratory CVs are in turn lower. These figures can also be put into perspective with the intra- and inter-laboratory variation coefficients of the acute $D$. magna ringtest organised by the Commission of the European Communities in 1978 with potassium dichromate (already mentioned above) which were $14 \%$ and $39 \%$ respectively.

The mean data of the ringtest performed with potassium chloride in 2005 are given in Table IX and basically confirm the findings of the two exercises with potassium dichromate. Statistical analysis of the data by the organisers of this ringtest (Baudo et al., 2006) also revealed no significant differences between the $24 \mathrm{~h}$ EC50s for the tests with the two types of Daphnia neonates.

Table IX shows that the intra-laboratory variation coefficients for $\mathrm{KCl}$ tests are low and similar for the two types of organisms (5-7\%). The inter-laboratory variation coefficients in turn are high for the lab culture tests (43\%), but substantially lower (21\%) for the Daphnia microbiotests. 


\section{Table X}

Results of the acute D. magna assays performed on the eluates of three solid wastes, with lab culture tests and with Daphnia microbiotests.

Tableau X

Résultats de tests aigus vis-à-vis de $D$. magna exécutés sur des éluats de trois déchets solides, avec des organismes de cultures de laboratoire et des microbiotests Daphnia.

\begin{tabular}{|l|c|c|c|c|c|}
\hline Waste & Origin of test organisms & Number of tests & $\begin{array}{c}\text { Mean 24 h } \\
\text { EC50 (in \%) }\end{array}$ & $\begin{array}{c}\text { Range of } \\
\text { EC50s }\end{array}$ & $\begin{array}{c}\text { CV } \\
(\%)\end{array}$ \\
\hline INC & Lab cultures & 39 & 3.32 & $0.90-6.90$ & 55 \\
& Daphnia microbiotests & 8 & 2.41 & $1.09-4.29$ & 41 \\
\hline WOO & Lab cultures & 40 & 0.42 & $0.05-1.65$ & 90 \\
& Daphnia microbiotests & 11 & 0.61 & $0.29-0.97$ & 32 \\
\hline SOI & Lab cultures & 40 & $>100$ & n.t. & n.t. \\
& Daphnia microbiotests & 11 & $>100$ & n.t. & n.t. \\
\hline
\end{tabular}

n.t. $=$ not toxic.

\section{European Union ecotoxicological ringtest on solid wastes}

In the framework of the European waste legislation which defines hazard criteria for the characterisation of hazardous waste types, a ringtest was organised in 2006 by the European Union under the coordination of the German Umweltbundesambt (UBA) for the selection of a test battery for ecotoxicological characterization of solid waste.

Participating laboratories received three types of solid wastes on which they had to perform standard toxicity tests either on the solid waste itself or on its eluates.

The three types of wastes selected for the ringtest that were sent to the participating laboratories included an incineration ash (INC), a waste wood (WOO) and a soil from an abandoned industrial site (SOI).

More than 60 laboratories from various countries in Europe participated in this ringtest with one or more standard bioassays, also including the acute D. magna test. The Daphnia assays had to be performed according to the ISO standard 6341 on the waste eluates which had to be prepared "in house" according to specific instructions.

The majority of the toxicity data submitted to the organizers for the $D$. magna tests originate from assays performed with organisms from lab cultures, but about a dozen laboratories also provided results obtained with Daphnia microbiotests.

A comparison was made on sensitivity and precision of the Daphnia microbiotests performed in the framework of this European ringtest (Persoone and Wadhia, 2008). A general comparison was furthermore also made between the results of several Toxkit microbiotests applied by some participants and standard ecotoxicological tests (Wadhia and Persoone, 2008).

The findings for eluates generated with the INC, WOO and SOI wastes assessed with the two types of test organisms are summarized in Table $X$.

As Table $X$ shows, four times more assays were performed in this ringtest with Daphnias from lab cultures than with neonates from Daphnia microbiotests.

Table X reveals that the eluate from the "industrial soil" (SOI) was not toxic when tested either by Daphnias from lab cultures or from dormant eggs.

The mean EC50s for the INC and WOO eluates calculated for the two types of Daphnia tests are not that different, but the range of the individual EC50s is larger for the tests with laboratory organisms. Wadhia and Persoone (2008) reported that all individual EC50s of the Daphnia microbiotests except one were within one standard deviation of the mean EC50 for the tests with lab cultured Daphnias. 
As can be noted from Table X, the variation coefficients of the Daphnia assays on the waste eluates are quite high, and even extremely high $(90 \%)$ for the tests on the WOO eluate with Daphnias from lab cultures. Very high variation coefficients have also been obtained in this European ringtest with several other types of toxicity tests. According to the organisers part of the variability originated from differences in the composition of the waste samples sent to the individual laboratories and from technical problems during the preparation of eluates.

Irrespective of these interferences not related to the "biological material" per se, Table $X$ shows that in this ringtest the CVs for the Daphnia microbiotests were lower than those of the lab culture tests. This finding again corroborates the greater precision of the Daphnia microbiotests, as already reported for the other ringtests outlined and discussed above.

Statistical analysis of the data revealed that the EC50s of the tests with lab cultured Daphnias did not follow a normal distribution, so a non parametric test (Shapiro Wilk) was applied to find out whether the mean EC50s obtained with the two types of test organisms were significantly different. This analysis showed that the mean EC50s for the INC eluate were not different, but those of the WOO eluate were in turn different at the $P<0.05$ level. This is probably due to the very high inter-laboratory variability of the EC50s of the tests performed on the WOO eluates with Daphnias from lab cultures. For the latter assays the spread between the lowest and the highest EC50s was as high by a factor of 33, as compared to the Daphnia microbiotests for which the two extreme EC50s only differed by a factor of 3.

This international ringtest thus also confirms the conclusions of the four other ringtests involving acute $D$. magna assays reported above, and which all show that the sensitivity of Daphnia neonates hatched from dormant eggs is similar to that of Daphnias originating from laboratory cultures.

\section{SENSITIVITY OF DIFFERENT STRAINS OF DAPHNIA MAGNA}

An aspect not yet dealt with in this review concerns the differences in sensitivity to toxicants between different clones of $D$. magna, reported by Baird et al. (1990).

Possible differences in sensitivity of neonates hatched from ephippia originating from different $D$. magna strains must therefore also be addressed.

In this regard the results of the quality control tests reported in Table III for different laboratories are a good reflection of all the factors which determine the "laboratory specific" sensitivity of the concerned $D$. magna strain. From these data, it appears that the laboratory specific "variability component" is in fact a much more important factor than the genetic origin of the $D$. magna strain, as shown by the (relatively large) range of the mean EC50s from the individual laboratories, and the overlapping of many QC test values with those of the other labs.

With regard to the sensitivity of test organisms hatched from dormant eggs of different $D$. magna strains, investigations were undertaken during the course of the development of the Daphtoxkit microbiotest in the laboratory at the Ghent University in Belgium.

Sensitivity comparisons were carried out on neonates hatched from ephippia, originating from four different $D$. magna strains.

The ephippia from the first strain were produced in the laboratory by a Daphnia culture started with organisms obtained from the laboratory LIEBE at the University of Metz in France.

The next two types of ephippia were obtained from cultures started with Daphnias harvested in ponds at two sites in Flanders, Belgium. The fourth type of ephippias was collected from another pond in Flanders, Belgium and the neonates hatched from the dormant eggs were used "directly" for the assays.

Table XI gives the mean $24 \mathrm{~h}$ EC50s for assays performed on potassium dichromate with the neonates hatched from these ephippia and shows that all values are situated in the range 1.00-1.31 $\mathrm{mg} \cdot \mathrm{L}^{-1}$. This range is similar to that reported in Tables III and IV for QC tests 


\section{Table XI}

Sensitivity comparison of neonates hatched from ephippia from different D. magna strains. Mean 24 h EC50s for potassium dichromate with the corresponding coefficients of variation.

Tableau XI

Comparaison de la sensibilité des néonates éclos d'ephippies de différentes souches de $D$. magna. Valeurs moyennes des CE50 24 h sur le bichromate de potassium, avec les coefficients de variation correspondants.

\begin{tabular}{|l|c|c|c|}
\hline Origin of strain & Number of tests & $\begin{array}{c}24 \mathrm{~h} \mathrm{EC50} \\
\left(\mathrm{mg}^{-1}\right)\end{array}$ & CV (\%) \\
\hline Culture from the University of Metz (France) & 3 & 1.31 & 11 \\
\hline Pond in Assenede (Flanders, Belgium) & 4 & 1.01 & 10.5 \\
\hline Pond in Zwijnaarde (Flanders, Belgium) & 6 & 1.02 & 17.5 \\
\hline Pond in Maaltebrugge park (Flanders, Belgium) & 1 & 1.00 & n.a. \\
\hline
\end{tabular}

* Test performed with neonates hatched from the ephippia collected from the pond. n.a. $=$ not applicable.

with Daphnias from either lab stock cultures or hatched from dormant eggs. The coefficients of variation of the assays are not larger either than those reported for the QC tests with Daphnia microbiotests.

An interesting series of comparative investigations was also made by Moreira dos Santos (1998) on the sensitivity of lab cultured $D$. magna of one of the former four $D$. magna strains (strain K5 from France) and of another strain collected from a pond in the UK (strain F2), versus that of neonates hatched from ephippias produced by the latter two strains.

For the latter strain, the Daphnia microbiotests were performed with the neonates hatched "directly" from field-collected ephippia.

The assays were performed on three organic chemicals: 2,4-dichlorophenoxyacetic acid $(2,4-\mathrm{D})$, malathion and sodium pentachlorophenol (NaPCP).

Statistical analysis (Student t-tests) of the data of the individual tests for which the mean $24 \mathrm{~h}$ EC50s are reported in Table XII revealed that there is no statistical difference (at the $P=0.05$ level) between the $24 \mathrm{~h}$ EC50s of the "ephippia neonates" and those of the lab cultured Daphnias, neither for strain K5 nor for strain F2, for each of the three analysed chemicals.

Comparison of the mean $24 \mathrm{~h}$ EC50s for 2,4-D and for malathion furthermore shows that the two values of the $\mathrm{K} 5$ and the F2 strains are quite close to each other for both the lab cultured Daphnias and the ephippia neonates. Taking into account the respective variation coefficients, it can therefore be concluded that the sensitivity of the two strains is basically the same for either the lab cultured Daphnias or the ephippia neonates.

The overall conclusion which can hence be drawn from these comparative experiments with ephippias from different $D$. magna strains is that the sensitivity of the neonates hatched from dormant eggs is not different from that of Daphnias from laboratory cultures.

\section{GENERAL DISCUSSION AND CONCLUSIONS}

\section{>1. TEST SENSITIVITY}

All the data from the numerous comparative studies performed with Daphnias from lab cultures or with Daphnia microbiotests at intra- as well as at inter-laboratory levels, revealed that both types of neonates have the same sensitivity for pure chemicals as well as for environmental samples. 
Table XII

Sensitivity comparison of lab cultured D. magna of strains K5 (France) and F2 (UK) and of neonates hatched from ephippia produced by these two strains. Mean $24 \mathrm{~h}$ EC50s for assays performed on three chemicals, with the corresponding coefficients of variation (data from Moreira dos Santos, 1998).

Tableau XII

Comparaison de la sensibilité de $D$. magna de cultures de laboratoire des souches K5 (France) et F2 (Grande-Bretagne) vis-à-vis de néonates éclos des ephippies produites par ces deux souches. Valeurs moyennes des CE50 24 h d'essais exécutés avec trois produits chimiques avec les coefficients de variation correspondants (données de Moreira dos Santos, 1998).

\begin{tabular}{|l|c|c|c|c|c|c|c|}
\hline & & \multicolumn{3}{|c|}{ Lab cultured Daphnias } & \multicolumn{3}{c|}{ Ephippia neonates } \\
\hline & $\begin{array}{c}\text { Number } \\
\text { of tests }\end{array}$ & $\begin{array}{c}\text { Mean } 24 \mathrm{~h} \\
\text { EC50 }\left(\mathrm{mg}^{-1}\right)\end{array}$ & $\begin{array}{c}\text { CV } \\
(\%)\end{array}$ & $\begin{array}{c}\text { Number } \\
\text { of tests }\end{array}$ & $\begin{array}{c}\text { Mean 24 h EC50 } \\
\left(\mathrm{mg}^{-1} \mathrm{~L}^{-1}\right)\end{array}$ & $\begin{array}{c}\mathrm{CV} \\
(\%)\end{array}$ \\
\hline Strain K5 & $2,4-\mathrm{D}^{\star}$ & 3 & 319.4 & 16 & 3 & 307.6 & 16 \\
\hline Strain F2 & $2,4-\mathrm{D}$ & 5 & 307.7 & 22 & 5 & $274.9^{\star \star \star}$ & 20 \\
\hline Strain K5 & Malathion & 5 & 0.00551 & 19 & 5 & 0.00426 & 18 \\
\hline Strain F2 & Malathion & 5 & 0.00369 & 27 & 5 & $0.00372^{\star \star \star}$ & 26 \\
\hline Strain F2 & NaPCP & 3 & 0.98 & 36 & 3 & 1.01 & 31 \\
\hline
\end{tabular}

* 2,4-dichlorophenoxyacetic acid.

** Sodium pentachlorophenol.

${ }^{\star \star \star}$ Tests performed with neonates hatched from the ephippia collected from the pond.

The tables in the present review on quality control tests and ringtests performed with potassium dichromate with Daphnia microbiotests, indicate that the $24 \mathrm{~h}$ EC50s of all assays are within the sensitivity range $\left(0.6-2.1 \mathrm{mg} \cdot \mathrm{L}^{-1}\right)$ set by ISO standard 6341 as a validity criterion for the assay sensitivity. These tables also show that the mean $24 \mathrm{~h}$ EC50s of the QC tests with potassium dichromate performed in several laboratories over a period of several years, and the mean $24 \mathrm{~h}$ EC50s of the Daphnia microbiotests from the ringtests on the acute $D$. magna assay, are near the mean value $\left(1.12 \mathrm{mg} \cdot \mathrm{L}^{-1}\right)$ indicated in ISO 6341 for this reference compound.

The former facts and figures thus provide convincing proof that from the point of view of "sensitivity" acute $D$. magna tests can be performed either with neonates from laboratory cultures or with neonates hatched from dormant eggs.

\section{>2. TEST PRECISION}

From data given in the tables it appears that despite all efforts for optimal standardization of the acute $D$. magna assay performed with organisms taken from laboratory cultures the variation coefficients for the intra-laboratory repeatability are in a number of cases quite high. As emphasized above, a distinction has, however, to be made in this regard between the intra-laboratory data of tests performed in duplicate or repeated within a very short period of time, and the long term quality control tests carried out in a particular laboratory during the course of several years (statistical control charts). Precision of the long-term quality control tests is generally somewhat worse than that of duplicated reference tests or assays performed concurrently or within a few days. This difference could actually be expected since QC tests are specifically intended to investigate the variability "over time" for the same laboratory, which obviously is well versed in routinely applied assays. Laboratory intercomparisons aim to quantify the "average" repeatability of different labs, some of which are perhaps using that assay for the first time or only sporadically. 
According to the potassium dichromate data reported in the present review for both lab culture tests and Daphnia microbiotests, long-term intra-laboratory variability of quality control tests are in the 20 to $30 \%$ range. This range is actually the same as that indicated in the Guidance Document on Control of Toxicity Test Precision using reference Toxicants published by Environment Canada in 1990.

As already indicated at several places in this review, the "magnitude" of the variability of intra-laboratory tests with reference chemicals is related to the type of chemical compound and this fact must definitely be taken into consideration in the evaluation of the degree of precision of acute $D$. magna tests with reference chemicals.

As shown in 1978 in the first $D$. magna ringtest organised by the Commission of the European Communities, inter-laboratory variability coefficients are higher than (short-term) intra-laboratory CVs, and this finding has since been corroborated since by most of the studies dealt with in this review.

The inter-laboratory variability found in various ringtests with pure chemicals as well as with industrial effluents or waste leachates analysed in the present review range from relatively low (CVs of $20 \%$ ) up to quite high values (CVs up to $80-90 \%$ ). Yet, as mentioned above for tests on reference compounds, high CVs have to be put in perspective with the chemical nature of the toxicant. In addition, and as was the case in the recent European Union ringtest on wastes, part of the very high inter-laboratory variation coefficients are not related to the ecotoxicity test but are due to (different) preparation of the waste leachates.

Moreover, the inter-laboratory comparisons of lab culture tests and Daphnia microbiotests all indicate that the precision of acute $D$. magna assays based on $D$. magna neonates from dormant eggs is in the majority of cases substantially better (i.e. the variability is lower) than that of the tests performed with organisms taken from lab cultures.

\section{> 3. TEST VALIDITY}

According to most international and national norms or guidelines on the acute $D$. magna assay, the percentage mortality or immobilization of the organisms in the controls should be $\leq 10 \%$ at the end of the exposure time. This criterion is always fulfilled if the Daphnia microbiotests are performed properly.

This is also the case for the second validity criterion, namely an oxygen concentration in the controls of at least $2 \mathrm{mg} \cdot \mathrm{L}^{-1}$ (ISO, 1996) or $3 \mathrm{mg} \cdot \mathrm{L}^{-1}$ (OECD, 2004) at the end of the test.

Finally, the third validity criterion, namely the sensitivity of the toxicity test as assessed from assays on a reference toxicant, is also fulfilled using Daphnia microbiotests as shown by the data above.

\section{RECOMMENDATIONS}

All standard test procedures on $D$. magna assays indicate that test organisms have to be taken from laboratory cultures (with detailed specifics on the culturing and the maintenance conditions of the cultures).

The rationale for this "historical" statement in the norms and guidelines on the acute $D$. magna test is in fact quite logical. The technology for controlled production of dormant $D$. magna eggs had indeed only been developed in the 1990s and dormant $D$. magna eggs have only became widely available for toxicity testing some years later.

Studies on the sensitivity of neonates hatched from dormant eggs and precision of Daphnia microbiotests have therefore only been conducted since the last decade.

Conclusive evidence on the similar sensitivity and the similar (and even better) precision of Daphnia microbiotests in comparison to lab culture assays is therefore relatively recent and not yet incorporated in national and international norms and guidelines. 
Several countries have, however, already taken the lead in allowing the use of Daphnia microbiotests for application in a regulatory framework.

The obvious advantages of Daphnia microbiotests over lab culture tests have gradually led to the worldwide use of these culture/maintenance free and low cost small-scale assays in both research and toxicity monitoring. According to recent calculations about 10000 acute $D$. magna assays are already performed annually with neonates hatched from dormant eggs. It is worthy to mention that the "adoption" by national and international organisations of the use of test organisms originating from dormant eggs is actually already a fact for toxicity tests with other commonly used test species. As an example in France the AFNOR standardisation organisation endorsed several years ago the possible use of "dormant eggs" in their own norms for chronic toxicity tests with the rotifer Brachionus calyciflorus and the crustaceans $D$. magna and Ceriodaphnia dubia.

At the international level, ISO has also recently "opened the door" to the use of dormant eggs, namely in ISO 20665 (2008) related to the determination of chronic toxicity to Ceriodaphnia dubia, and in ISO 20666 (2008) for the determination of the chronic toxicity to Brachionus calyciflorus in $48 \mathrm{~h}$.

The present review paper collected and reviewed all the scientific evidence showing that $D$. magna neonates obtained by hatching of dormant eggs also comply with all criteria and conditions set by national and international organisations for test organisms taken from laboratory cultures, for their use in acute toxicity tests.

It is the intention of the authors of this review to make this evidence known to those who are responsible at the national and international level for the rules and specifics of the acute D. magna toxicity test method.

The convincing evidence given in this review will hopefully trigger action linked to the next revision of the acute $D$. magna test procedure, whereby performers will be able to choose neonates of their liking - i.e. stemming from laboratory cultures or from dormant eggs - in the conduct of toxicity tests with this or with other invertebrate species, as some other recently endorsed norms and guidelines already indicate.

\section{ACKNOWLEDGMENTS}

The authors express their sincere thanks to all the laboratories, institutes and organisations that kindly provided information and data for this review. Special thanks are given in particular to Ms. E. Jonczyk and Dr. L. Novak of Aquatox Testing and Consulting, Inc., Guelph, Canada, Dr. K. Zsuga, Environmental Protection and Water Management Research Institute, Hungary, Mrs. A. Van Cauwenberghe, Institut Provincial d'Hygiène et de Bactériologie, Mons, Belgium, Mr. Tony Brouwers, LISEC, Genk, Belgium, Dr. K. Wadhia, NCIMB, Buckburns, Aberdeen, Scotland, Dr. Y. Marneffe, ISSEP, Cellule Écotoxicologie, Liège, Belgium, Dr. R. Weltens, VITO, Environmental Toxicology, Mol, Belgium, M.J. Benitez de Huelva, Laboratorio de Microbiologia y Toxicologia Experimental, Grupo Interlab, Madrid, Spain, Dr. S.A. Kools, Grontmij/Aquasense, Amsterdam, the Netherlands, Mrs. A. Taljet, Institute of Public Health, Nova Gorica, Slovenia, Dr. A. Drolc, NIC, Laboratory for Environmental Science and Engineering, Ljubljana, Slovenia; Mr. K. Perdaen and Mr. W. Lanneau, MicroBioTests Inc., Mariakerke, Belgium.

\section{REFERENCES}

Baird J., Barber I., Bradley M., Calow P. and Soares A.M.V.M., 1989. The Daphnia bioassay: a critique. Hydrobiologia, 188-189, 1, 403-406.

Baird D.J., Barber I. and Calow P., 1990. Clonal variation in general responses of Daphnia magna to toxic stress. I. Chronic life-history effects. Funct. Ecol., 4, 339-407. 
Baudo R., Sbalchiero A. and Beltrami M., 2004. Test di tossicità acuta con Daphnia magna. Biologi Italiani, 6, 62-69.

Baudo R., Sbalchiero A. and Beltrami M., 2006. National intercomparisons acute toxicity test with Daphnia magna. Report to the Agenzia per la Protezione dell'Ambiente e per I Servizi Technici, Roma, Italy, Internal document, $13 \mathrm{p}$.

Blaise C., 1991. Microbiotests in aquatic ecotoxicology: Characteristics, utility and prospects. Environ. Toxicol. Water Qual., 6, 145-155.

Broderius S.J., 1983. Analysis of an inter-laboratory comparative study of acute toxicity tests with freshwater aquatic organisms, US Environmental Protection Agency, Duluth, USA.

Buikema A.L., 1983. Variation in static acute toxicity test results with Daphnia magna exposed to refinery effluents and reference toxicants. Oil \& Petrochemical Pollution, 1, 3 189-198.

Bulich A.A. and Isenberg D.L., 1980. Use of the luminescent bacterial system for the rapid assessment of aquatic toxicology. Adv. Intrum., 80, 35-40.

Canton J.J. and Adema D.M.M., 1978. Reproducibility of short-term and reproduction toxicity experiments with Daphnia magna and comparison of the sensitivity of Daphnia magna with Daphnia pulex and Daphnia cucullata in short-term experiments. Hydrobiologia, 59, 135-140.

Commission of the European Communities, 1979. Inter-laboratory ringtest concerning the study of the ecotoxicity of a chemical substance with respect to the Daphnia, Study D.8369, $18 \mathrm{p}$.

Commission of the European Communities, 1992. Commission Directive 92/69/EEC of 31 July 1992 adapting to technical progress for the 17th time Council Directive 67/548/EEC on the approximation of laws, regulations and administrative provisions relating to the classification, packaging and labelling of dangerous substances, C.2. Acute toxicity test Daphnia.

Cotman M., Drolc A. and Ros M., 2003. An inter-laboratory study to improve the quality of chemical and biological measurements in waste water. Accred. Qual. Assur., 8, 156-160.

Cotman M., Drolc A., Ros M. and Tisler T., 2007. Daphnia magna wastewater toxicity assays: an interlaboratory study. Int. J. Environ. Poll., 31, 1/2, 13-21.

Cotman M., Drolc A. and Tisler T., 2009. Inter-laboratory studies on waste water toxicity using Daphnia magna. Accred. Qual. Assur., 14, 319-327.

Daniel M., Sharpe A., Driver J., Knight A.W., Keenan P.O., Walmsley R.M., Robinson A., Zhang T. and Rawson D., 2004. Results of a technology demonstration project to compare rapid aquatic toxicity screening tests in the analysis of industrial effluents. J. Environ. Monit., 6, 855-865.

Environment Canada, 1990. Guidance document on control of toxicity test precision using reference toxicants, Environmental Protection, Conservation and Protection, Report EPS 1/RM/12, Ottawa, Ontario, Canada, $85 \mathrm{p}$.

Environment Canada, 1996. Biological test method: Acute lethality test using Daphnia spp., Report EPS 1/RM/11, $55 \mathrm{p}$.

Fochtman P., 2000. Acute toxicity of nine pesticides as determined with conventional assays and alternative microbiotests. In: Persoone G., Janssen C. and De Coen W. (eds.), New Microbiotests for Routine Toxicity Screening and Biomonitoring, Kluwer Academic/Plenum Publishers, 233-242.

Gersich F.M., Blanchard F.A., Applegath S.L. and Park C.N., 1986. The precision of daphnid (Daphnia magna Straus, 1820) static acute toxicity tests. Arch. Environ. Contam. Toxicol., 15, 741-749.

Grothe D.R. and Kimerle R.A., 1985. Inter- and intra-laboratory variability in Daphnia magna effluent toxicity test results. Environ. Toxicol. Chem., 4, 189-192.

ISO 6341:1996. Water Quality - Determination of the inhibition of the mobility of Daphnia magna Straus (Cladocera, Crustacea) - Acute toxicity test.

ISO 20665:2008. Water Quality - Determination of chronic toxicity to Ceriodaphnia dubia.

ISO 20666:2008. Water Quality - Determination of chronic toxicity to Brachionus calyciflorus in $48 \mathrm{~h}$.

Janssen C.R., 1998. Alternative assays for routine toxicity assessments: a review. In: Schüürman G. and Markert B. (eds.), Ecotoxicology, Wiley \& Sons, 813-839.

Jonczyk E. and Gilron G., 2005. Acute and chronic toxicity testing with Daphnia sp. In: Blaise C. and Férard J.-F. (eds.), Small-scale Toxicity Testing for freshwater Environments, Kluwer Academic/Plenum Publishers, 337-394.

Jop K.M., Rodgers J.H., Dorn P.B. and Dickson K.L., 1986. Use of hexavalent chromium as a reference toxicant in aquatic toxicity tests. In: Poston T.M. and Purdy R. (eds.), Aquatic Toxicology and Environmental Fate, 9th Vol. ASTM STP 921, American Society for Testing and Materials, Philadelphia, USA, 390-403.

Latif M. and Zach A., 2000. Toxicity studies of treated residual wastes in Austria using different types of conventional assays and cost-effective microbiotests. In: Persoone G., Janssen C. 
and De Coen W. (eds.), New Microbiotests for Routine Toxicity Screening and Biomonitoring, Kluwer Academic/Plenum Publishers, 367-383.

Lewis P.A. and Horning W.B., 1991. Differences in acute toxicity test results of three reference toxicants on Daphnia at two temperatures. Environ. Toxicol. Chem., 10, 1351-1357.

Lewis P.A. and Weber C.I., 1985. A study on the reliability of Daphnia acute toxicity tests. In: Cardwell R.D., Purdy R. and Bahner R.C. (eds.), Aquatic Toxicology and Hazard Assessment, 7th Symposium, ASTM STP 854, R.D. American Society for Testing and Materials, Philadelphia, USA, 73-76.

Moreira dos Santos M., 1998. The controlled production and hatching of ephippia of Daphnia magna (Crustacea, Cladocera) for toxicity testing. Ph.D. Thesis, Ghent University, Belgium, 372 p.

OECD, 1984. Daphnia sp. Acute Immobilisation Test and Reproduction Test, OECD Guideline for the testing of chemicals, Guideline 202.

OECD, 2004. Daphnia sp. Acute Immobilisation Test, OECD Guideline for the testing of chemicals, Guideline 202.

Ontario Ministry of the Environment, 2002. Guidance document for acute lethality testing of metal mining effluents, Report E1191 prepared by ESG International and B. Zajdlik and Associates, 60 p.

Parker W.R., 1983. Results of an inter-laboratory study on the toxicity of potassium dichromate to Daphnia, Laboratory Division, Air and Water Branch, Environmental Protection Service, Environment Canada, Atlantic Region, $36 \mathrm{p}$.

Parkhurst B.R., Warren-Hickx W. and Noel L.E., 1992. Performance characteristics of effluent toxicity tests: summarization and evaluation of data. Environ. Toxicol. Chem., 11, 6, 771-791.

Persoone G., 1992. Cyst-based toxicity tests I. A promising new tool for rapid and cost-effective toxicity screening of chemicals and effluents. Z. Angew. Zool., 78, 2, 235-241.

Persoone G., 1998. Development and first validation of Toxkit microbiotests with invertebrates, in particular crustaceans. In: Wells P.G., Lee K. and Blaise C. (eds.), Microscale Testing in Aquatic Toxicology - Advances, Techniques and Practice, C.R.C. Publishers, Chapter 30, 437-449.

Persoone G., 2001. Microbiotests for rapid and cost-effective hazard assessment of industrial products, effluents, wastes, waste leachates and groundwaters. In: Clark S.A., Thompson K.C., Keevil C.W. and Smith M.S. (eds.), Rapid detection assays for food and water, Royal Society of Chemistry, Cambridge, UK, Special Publication 272, 109-115.

Persoone G., 2004. Variability of the ecotoxicity of industrial waste waters - Comparison of the sensitivity of conventional toxicity tests with that of Toxkit microbiotests, Report of a study commissioned by the Flemish Environmental Agency in Belgium (in Dutch), 29 p.

Persoone G. and Van de Vel A., 1987. Cost-analysis of 5 current aquatic ecotoxicological tests, Commission of the European Communities, Environment and Quality of Life, Report EUR 1134 EN, $119 \mathrm{p}$.

Persoone G. and Wadhia K., 2008. Comparison between Toxkit microbiotests and standard tests. In: Moser H. and Römbke J. (eds.), Ecotoxicological Characterization of Waste - Results and Experiences from an International Ring Test, Springer Publisher, Chapter 23, 213-221.

Rue W.J., Fava J.A. and Grothe D.R., 1988. A review of inter- and intra-laboratory effluent toxicity test method variability. In: Adams W.J., Chapman G.A. and Landis W.G. (eds.), Aquatic Toxicology and Hazard Assessment, 10th Vol. STP 971, American Society for Testing and Materials, Philadelphia, USA, 190-203.

Ruymen V., Vreys C., Witters H., Vandenbroele M., Heijerick D. and Van Sprang P., 2003. Variability of the ecotoxicity of industrial wastewaters, Study commissioned by the Environmental Agency of Flanders, LISEC Report VR-2003-17907 (in Dutch), 63 p.

Ulm L., Vrzina J., SchiesI V., Puntaric D. and Smit Z., 2000. Sensitivity comparison of the conventional acute Daphnia magna immobilization test with the Daphtoxkit $\mathrm{F}^{\mathrm{TM}}$ microbiotest for household products. In: Persoone G., Janssen C. and De Coen W. (eds.), New Microbiotests for Routine Toxicity Screening and Biomonitoring, Kluwer Academic/Plenum Publishers, 247-252.

United States Environmental Protection Agency (USEPA), 2001. Methods for measuring the acute toxicity of effluents and receiving waters to freshwater and marine organisms, Fifth edition, EPA821-R-02-012, Washington DC, USA, $266 \mathrm{p}$.

Wadhia K. and Persoone G., 2008. Toxkit microbiotests. In: Moser H. and Römbke J. (eds.), Ecotoxicological Characterization of Waste - Results and Experiences from an International Ring Test, Springer Publisher, Chapter 13, 145-152.

Whitehouse P., Crane M., Redshaw C.J. and Turner C., 1996. Aquatic toxicity tests for the control of effluent discharges in the UK - the influence of test precision. Ecotoxicology, 5, 155-168. 